\title{
Article \\ Elementome of Endemic Dolomitic Flora: Pterocephalus spathulatus (Lag.) Coult
}

\author{
Encarna Merlo (D), Antonio J. Mendoza-Fernández *(D), Esteban Salmerón-Sánchez (D), Fabián Martínez-Hernández (D), \\ Andrea Ortiz-Úbeda (D) and Juan Mota (D)
}

\author{
Department of Biology and Geology, CEI-MAR and CECOUAL, University of Almería, E-04120 Almería, Spain; \\ emerlo@ual.es (E.M.); esanchez@ual.es (E.S.-S.); fmh177@ual.es (F.M.-H.); aou628@inlumine.ual.es (A.O.-Ú.); \\ jmota@ual.es (J.M.) \\ * Correspondence: amf788@ual.es
}

check for

updates

Citation: Merlo, E.;

Mendoza-Fernández, A.J.;

Salmerón-Sánchez, E.;

Martínez-Hernández, F.; Ortiz-Úbeda,

A.; Mota, J. Elementome of Endemic

Dolomitic Flora: Pterocephalus

spathulatus (Lag.) Coult. Land 2021,

10, 1253. https://doi.org/10.3390/

land10111253

Academic Editor:

Manuel López-Vicente

Received: 8 October 2021

Accepted: 12 November 2021

Published: 16 November 2021

Publisher's Note: MDPI stays neutral with regard to jurisdictional claims in published maps and institutional affiliations.

Copyright: (c) 2021 by the authors. Licensee MDPI, Basel, Switzerland. This article is an open access article distributed under the terms and conditions of the Creative Commons Attribution (CC BY) license (https:// creativecommons.org/licenses/by/ $4.0 /)$.

\begin{abstract}
Unusual dolomite substrates present a phenomenon known as dolomitophily, which refers to the specificity of the flora that grows on them. Within the dolomitic flora, one of the most widespread plants in Spain is the characteristic species Pterocephalus spathulatus (Lag.) Coult., which forms whitish prostrate thymes. The present study focused on the knowledge about the ionome (or elementome) of a characteristic dolomite species and some of its applications, both in terms of its nutritional behaviour and in determining the factors that favour the rich and rare flora growing on dolomitic soils. Soil, foliar, stem and root samples of the species studied were collected from different locations in the south of Spain. The samples were analysed to determine their mineral composition. The Bioconcentration Factor (BCF) and the Translocation Factor (TF) were calculated, relating the values of the mineral contents in the soil, both total and phytoavailable, to the values from the foliar, root and stem samples. It was found that this species was able to accumulate some elements, including $\mathrm{B}, \mathrm{Cr}, \mathrm{Cu}, \mathrm{Ni}, \mathrm{Ti}, \mathrm{Tl}$ and $\mathrm{Zn}$, which can be phytotoxic in high concentrations, and are considered to be some of the main toxic metals in soils. In addition, it was observed that the plant can accumulate metals in the stem and leaves (TF), thus proving that it is capable of transporting them from the root to the aerial part of the plant. The data obtained may indicate that other species in the plant community may possess this bioindicator or even phytoremediation capacity.
\end{abstract}

Keywords: Bioconcentration Factor; dolomite; heavy metals; ionome; phytoremediation; priority habitat; Translocation Factor

\section{Introduction \\ 1.1. Historic Context}

The influence of soil on vegetation has been documented since ancient times, e.g., Theophrastus (371-287 B.C.) stated: "And perhaps, it is appropriate to examine the places where each plant is born and where it is not. Because this is a conspicuous distinction and very characteristic of plants, since they are linked to the earth and not detached from it like animals". This influence depends both on the chemical factors associated with it, and on physical and biological ones.

The main studies in this field began in the 19th century with the works of Unger and Thurmann [1,2]. Unger [1] established scientifically the existence of a relationship between geology and plants, through his Chemical Theory of Soil [3]. According to this theory, the inorganic contents of the soil were the main causes of plant responses [4]. However, as is usual in science, the chemical theory proposed by Unger in 1836 was quickly countered by another that reduced the importance of chemical composition in the relationship between rock types and vegetation. The opposite theory, proposed by Thurmann in 1849 [2], focused on the physical characteristics of the soil to explain this relationship. In the 20th century, other proposals also emerged, such as Geoecology [5], which refers to the fact that plant distribution in certain areas is, almost exclusively, determined by edaphic factors. 
Rivas Goday [6] first coined the term edaphism in 1969, in reference to those plants closely related to a specific substrate. This term has been used in two senses, both to describe the geobotanical phenomenon that links plants to special rocks or soils, and as a contraction of "edaphic endemism" [4]. Whether used in one sense or another, edaphism is caused by a number of chemical and physical drivers. The chemical (or nutritional) factors are due to the mineral composition of the underlying rocks, which form the basis of soil $[7,8]$. The chemical nature of the soil has a great influence on the vegetation, giving rise to such a marked specificity that one can speak about typical floras of specific dolomitic habitats [4]. Thus, specific floras from serpentines, halophilic floras, gypsophilous floras, or any other sort of soils related to elements such as Se, $\mathrm{Zn}$ and other heavy metals, have been known for a long period of time $[9,10]$.

According to Mota et al. [8,11] and Merlo et al. [12,13], the relationship between the contents of $\mathrm{Ca}$ and $\mathrm{Mg}$ may be a key factor when it comes to understanding the different plant species or groups of them (flora) specifically associated with each substrate, and the plant communities (vegetation) that develop on them. In the case of dolomite, perhaps the most striking of all, the flora is dominated by upholstery species, endowed with a dense sericeous indumentum, which literally covers the ground although in a dispersed way. Interestingly, this type of vegetation is reminiscent of typical plant communities on coastal dunes due to its appearance or physiognomy [14], with serious conservation threats $[15,16]$. Coastal dunes and dolomitic soils, often also referred to as "sandy" soils, share a coarse texture that does not have a large capacity to retain moisture. This fact implies that, in addition to chemical characteristics, the physical conditions of the soil are crucial to interpret this geobotanical phenomenon. One of these physical factors is the extreme xericity conditioned also by several factors, such as topographical ones. These factors influence the water economy of plants through evotranspiration and the amount of light received. In addition, the micro-relief is responsible for generating heterogeneous spaces in which the availability of water and nutrients can vary enormously $[8,11-14,17]$.

\subsection{Properties and Characteristics of Dolomitic Soils}

A dolomitic rock is a carbonated rock composed of calcium carbonate and magnesium $\mathrm{CaMg}\left(\mathrm{CO}_{3}\right)_{2}$. Because of their chemical composition, dolomitic rocks can be mistaken for limestone. However, according to Chilingar [18] the difference between the two types of rocks lies in the proportion of calcite $\left(\mathrm{CaCO}_{3}\right)$ and dolomite $\left(\mathrm{MgCO}_{3}\right)$. In dolomitic rocks, the concentration of dolomite reaches $90 \%$, with a very low proportion of calcite, whereas in limestone the concentration of calcite exceeds $50 \%$, with low dolomite contents. Thus, dolomitic soils are characterised by high concentrations of $\mathrm{Ca}$ and $\mathrm{Mg}(3: 1)$, slightly basic $\mathrm{pH}$, and low concentrations of N, P, K and even Fe.

The extension of dolomitic rocks covers broad areas [14], from the White Mountains in USA, to areas in the Mediterranean Basin, where the Betic Mountain Ranges [19,20], the Taurus Mountains [21], the Balkans [22], the Alps [23], Crete [24], etc., are worthy of special attention, in addition to some areas of Asia, such as Anatolia, Tibet and the Himalayas, although there are no excessively specific references [25], and in the southern hemisphere, where their distribution extends through the southern part of Africa, Australia, and Tasmania [26].

However, they cannot always be easily differentiated from limestones. This has made it difficult to study the vegetation and flora associated with dolomitic outcrops [14]. Therefore, it is a complicated task, since there is a wide variety of habitats, to the point where up to seven rocky environments can be distinguished which have vegetation associated with dolomite presence [8]. Among these environments, cliffs may be highlighted, where verticality is key [27]. The same happens in the stony terrains located at the foot of the cliffs [28].

According to Mota et al. [14], there are a number of characteristics common to this type of soil that contribute to determining the phenomenon of dolomitophily. First, dolomitic soils are characterised by being poorly developed, and by their sandy or burdensome 
appearance due to the fragmentation and disaggregation of the bedrock. This property results from the fact that they occur in highly tectonized terrains [11], which causes severe stress in the area; this fact is responsible for not allowing the growth of vegetation similar to that in the surrounding territory. Another of its important characteristics is its low water retention capacity and, therefore, its lower capacity for nutrient accumulation, due to its slow weathering. In addition, it extends mainly on south-facing slopes and ridges where high insolation promotes erosion and drainage.

\subsection{Dolomiticolous Flora and Vegetation}

Although there is a limited variety of studies on the dolomitophily phenomenon, some research that focused on the study of dolomitic scrubs may be highlighted, especially regarding this vegetation found in the Betic Ranges, which has been included in the Andryalion agardhii Rivas-Martínez ex Rivas Goday \& Mayor 1966 alliance [4]. In this area, the works of Rivas Goday and Mayor [29], Mota et al. [30], Pérez-Latorre et al. [31], MedinaCazorla et al. [32-34], Navarro-Fernández et al. [35] and Alonso and García-Sevilla [36] are some of the publications that should draw attention. In more recent times, research has focused on the study of the degree of endemicity, genetic diversity, and edaphic and physiological analyses (e.g., Salmerón-Sánchez et al. [17,37,38]). However, although dolomitic soils and their flora are distributed in numerous regions worldwide, most studies have been developed in the Iberian Peninsula [11]. According to Medina-Cazorla [34], in the Betic Ranges more than 80 associated dolomitic plant species can be found. Among them, there are species that integrate prostrate and sericeous thymes communities [39], of whitish or greyish colouring [30], such as Arenaria delaguardiae G. López \& Nieto Fel., Erodium astragaloides Boiss. \& Reut., Helianthemum pannosum Boiss., Pterocephalus spathulatus (Lag.) Coult. or Convolvulus boissieri Steud.

Taken together, edaphic chemical and physical factors are responsible for generating very rare floras, rich in endemic plant species, which encompass characteristic plant communities (or types of vegetation). Dolomitic rocks present in the Betic Ranges deserve special attention due to their high phytodiversity [40]. They are rich in small sclerophyllous scrubs, frequently threatened [41], unique in the Mediterranean Basin [42] and catalogued as a priority for conservation by the European Union through the Habitats Directive [43]. Indicator or diagnostic plants species, often with a very narrow geographical distribution (regional and local endemism), are present in these communities. Richness in endemic plant species is not the only distinctive feature of these formations. They are easily recognisable by both their physiognomic characteristics and physiological adaptations to these ecosystems (Figure 1). In addition, it has been observed that this type of vegetation usually presents low productivity rates compared with the communities that surround it. Additionally, they are often distributed as edaphic habitat islands [44], which allows them to be studied from the perspective of island ecological biogeography [39]. In summary, the characteristics of dolomitic soils and the nutritional challenges faced by these plants may be behind the richness and diversity of these communities.

\subsection{Ionomic Studies in Plants}

The ionome (or elementome) is defined as the composition of mineral nutrients and trace elements present in an organism, thus representing the inorganic component of cellular systems. High-throughput elemental analysis technologies such as Inductively Coupled Plasma Spectrometry-Mass Spectrometry (ICP-MS) and Inductively Coupled Plasma Optical Emission Spectrometry (ICP-OES) are often used here [45]. The resulting knowledge often provides interesting advantages, including the possible isolation of genes responsible for mineral transport or homeostasis in plants [46,47]. In addition, it is also often applied in the research on the influences of phylogeny and environment on mineral accumulation in plants [48-50]. The ionome is controlled in plants by several physiological processes that occur in the rhizosphere; in the leaves by evotranspiration, in the movement of ions through the xylem or phloem to and from the shoot, respectively. In this way, any 
alteration in any of the aforementioned processes, which are involved in the transport of inorganic ions from the soil solution to the plant budding (by the transpirational current) and which then spread them from the leaves to the rest of the plant (including the radical system), can affect the ionic content of the whole plant. Therefore, the shoot ionome is very sensitive to the physiological state of the plant [51].
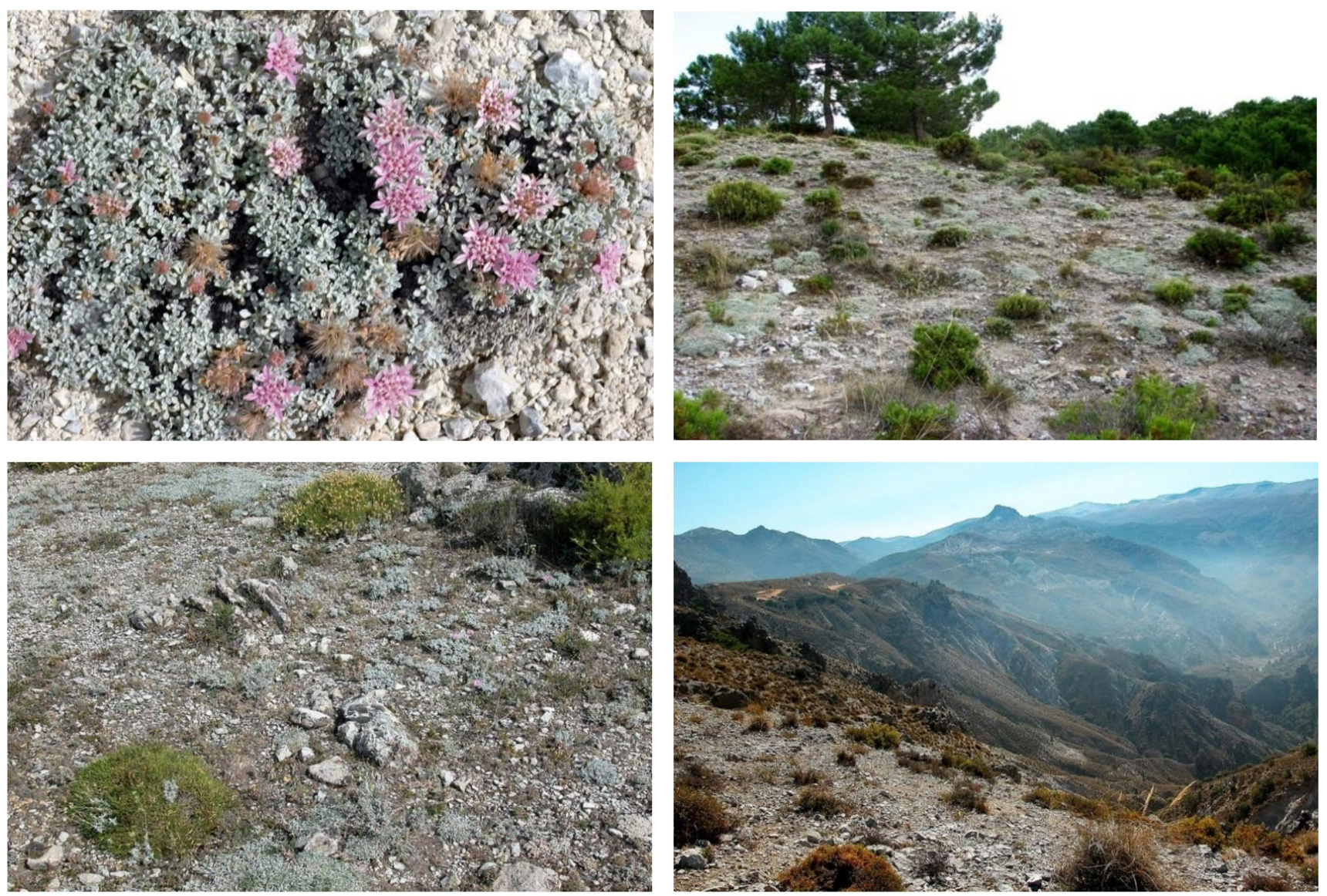

Figure 1. Images of plant species and dolomite vegetation community. (Top left): P. spathulatus; (top right): La Peza (Sierra de Huetor); (bottom left): Association Andryalo agardhii-Convolvuletum boissieri Quezel 1953 nom. inv.; (bottom right): Boca de la Pesca (Sierra Nevada). (Photos by J. Mota).

Research in this field has shown that plant ionome studies are key to understanding different ecosystems of the Earth $[52,53]$. These studies usually focus their attention on several key elements and their proportions, such as C:N or N:P:K ratios. In this sense, the $\mathrm{N}: \mathrm{P}: \mathrm{K}$ ratio has helped to understand the limitations imposed by each of these elements on plant growth [54,55]. In dolomitic soils, this kind of research has revealed that $\mathrm{P}$ is usually the most limiting nutritional element. Therefore, the affinity of dolomite flora for this type of rock may be due to its high tolerance to low P levels [56]. In the case of $\mathrm{Mg}$, there are certain processes that can help to understand the plant's adaptations to dolomitic soils. These include increased sugar transportation from the leaves to the roots, thus favouring root growth and increasing the surface area for water absorption, a fundamental aspect due to the low water retention capacity of dolomitic rocks [57-59]. In addition, the high $\mathrm{Mg}$ content in these habitats can lead to increased plant resistance to high temperatures and light intensities, which is very common in areas where dolomites are found [60].

The usefulness of ionomic studies can be focused in a practical way towards phytoremediation, defined as the ability of certain plants to remove contaminants from the environment, mostly heavy metals [61-63]. According to Brooks [64], the efficiency of a species to be used in phytoremediation techniques can be estimated by the Bioconcen- 
tration Factor (BCF) and the Translocation Factor (TF). Furthermore, depending on the values obtained, a plant can be classified as an indicator, accumulator or hyperacumulator $[65,66]$. In addition, new machine learning techniques can assist in proposing more objective thresholds when classifying plant species from this perspective [67]. In addition, ionomic studies may also be used to understand the properties and peculiarities of plant communities developing on particular substrates such as dolomites [14].

\subsection{Species under Study}

Pterocephalus spathulatus (Lag.) Coult. is an endemism of the Betic Ranges, and one of the most predominant species of the dolomite plant communities in southern Spain. The genus Pterocephalus ex Adans. (Caprifoliaceae) comprises about 30 species, distributed from Kurdistan to Macaronesia, including southeastern Africa (Ethiopia and Tanzania) [68]. P. spathulatus is a perennial herb with a highly branched trunk, the stems of which can be up to $25 \mathrm{~cm}$ long and are whitish in colour. The leaves are entire and spatulate and the flowers have a rough calyx and a pink or violet corolla (Figure 2).

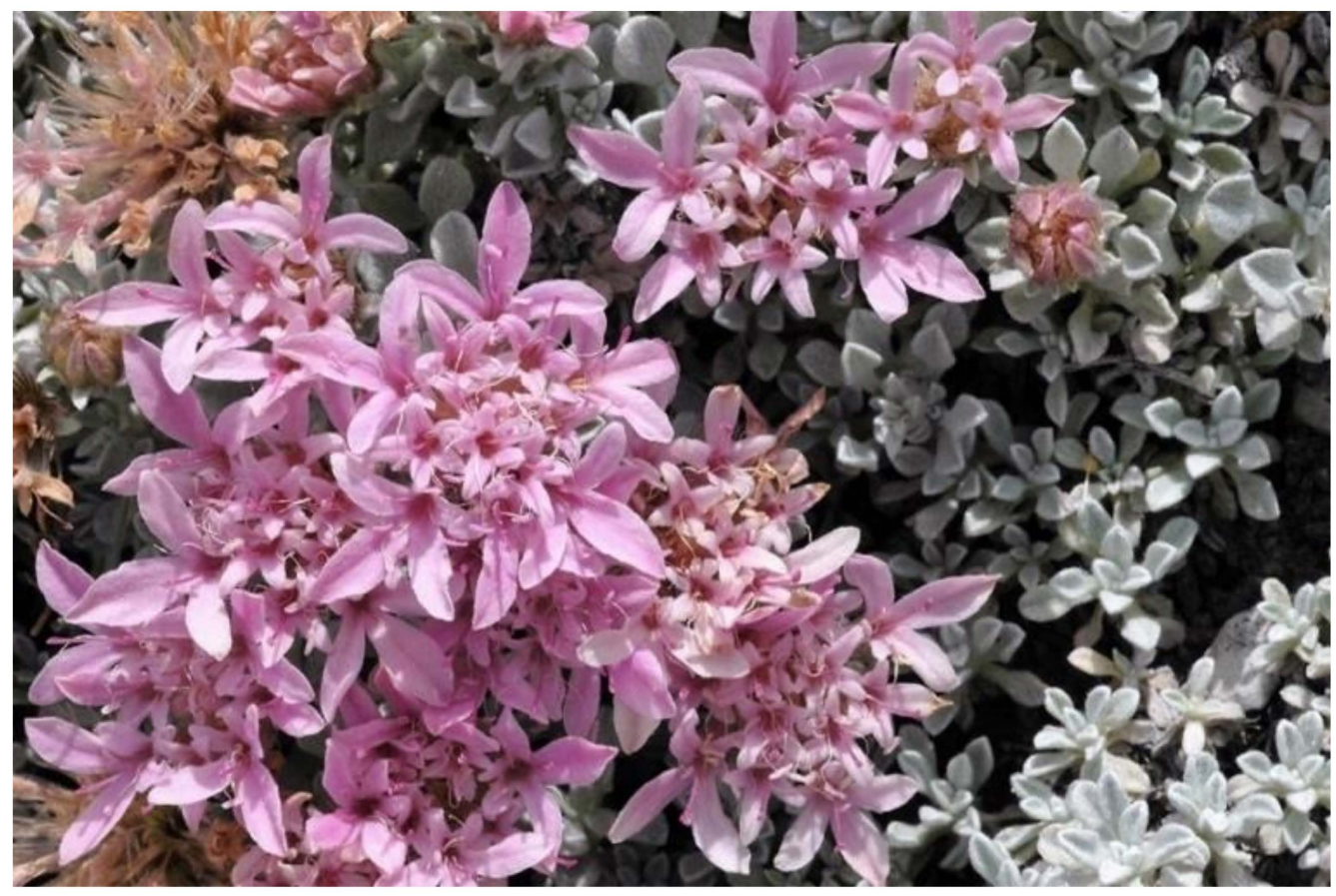

Figure 2. General appearance of the inflorescences and leaves of P. spathulatus (Photo by J. Mota).

Very little is known about the ionome of plants growing on dolomitic soils, although many are rare and endemic (and even threatened), such as P. spathulatus. Thus, the current study focused on characterising the ionomic composition of this species, and determining the usefulness of its knowledge, first, to assess its potential value as a bioindicator species for heavy metals or metaloids in soils (or at least to gain some insights into the potential phytoremediation utility among the dolomiticolous flora); and, second, to determine some reasons for the high richness and diversity of plant communities (from a nutritional point of view). Associated with this, four specific objectives were established:

- To determine the concentrations of the elements, both total and phytoavailable, found in the dolomitic soils where P. spathulatus is able to grow, as a reference system to which its ionomic composition may be related.

- To identify what elements, present in the soil (total) or in dissolution (phytoavailable), accumulate in different parts of the plant, mainly in leaves. In this way, this study sought to establish whether total or phytoavailable elements were the best predictors of the mineral composition of the plant, by calculating the Bioconcentration Factor (BCF). 
- To determine the relationship between the elements accumulated in leaves, stems and roots by means of the Translocation Factor (TF), in order to establish whether they are likely to concentrate in stems, and especially in leaves.

- To relate the influence of the mineral composition of the soil to the richness and diversity of the plant communities where the diagnostic species P. spathulatus grows.

\section{Materials and Methods}

\subsection{Study Area and Sampling}

Samples of P. spathulatus and paired soils were collected from nine locations (Table 1). These locations were selected to cover almost the entire range of this plant and to check for local variations in its elementome (Figure 3). In addition, they belong to different biogeographic sectors: Granadese-Almijarese (La Maroma, Boca de la Pesca, La Peza, Navachica and Los Alayos); Accitanian-Bastitanian (Calar del Gallinero), Alpujarrese-Gador Sierran (Gador) and Subbetic (Calar de la Puebla and Harana). Twenty-five specimens were sampled at each locality. Efforts were made to damage the plants as little as possible. Plant vouchers were collected and deposited at the herbarium of the University of Almeria (HUAL) (Table S1). For each sampling, permission was requested from the Consejeria de Medioambiente (Junta de Andalucia) in the framework of the project CGL2007-63563/BOS funded by the Spanish Ministry of Science and Innovation.

Table 1. Localities sampled with the acronyms (Cod.) used in the text.

\begin{tabular}{cccccc}
\hline Range & Study Area & Cod. & Altitude $(\boldsymbol{m})$ & $\boldsymbol{X}$ & $\boldsymbol{Y}$ \\
\hline Sierra de los Filabres & Calar del Gallinero & GAL & 2020 & 542733 & 4123047 \\
Sierra de Gador & Gador & GAD & 2180 & 515730 & 4084443 \\
Sierra de Huetor & La Peza & PEZ & 1085 & 461908 & 4123864 \\
Sierra Nevada & Boca de la Pesca & BOC & 1350 & 451598 & 4103580 \\
Sierra Nevada & Los Alayos & ALA & 1980 & 451598 & 4103580 \\
Sierra Harana & Harana & HAR & 2027 & 456418 & 4130782 \\
Sierra de Almijara & Navachica & NAV & 1832 & 429674 & 4082412 \\
Sierra de Tejeda & La Maroma & MAR & 2069 & 406846 & 4084642 \\
Sierra de la Sagra & Calar de la Puebla & PUE & 1800 & 547695 & 4199135 \\
\hline
\end{tabular}

\subsection{Soil Analysis}

At each location, three soil samples were taken from the first $10-15 \mathrm{~cm}$, as these were shallow soils. According to the World Reference Base for Soil Resources (https: / / www.isric.org/explore/wrb (accessed on 21 September 2021)) these soils are classified as Regosols due to the presence of dolomitic material throughout the range from 20 to $100 \mathrm{~cm}$ from the soil surface, or between $20 \mathrm{~cm}$ and continuous rock, technic hard material or a cemented or indurated layer. They were left to dry at room temperature for one week. Once the samples were dry, the contents of each soil sample were homogenised to make the analysis more reliable. The samples were sieved with a $200 \mu \mathrm{m}$ aperture steel sieve, removing any plant debris and gravel. From the sample obtained, ten grams were separated and ground in a mixer mill (Restch MM200) for $60 \mathrm{~s}$. One gram of each sample was used for soil analysis and three grams for the analysis of phytoavailable elements.

\subsubsection{Analysis of Total Soil Elements}

Soil samples were analysed in the Ionomics Laboratory of the Segura Edaphology and Applied Biology Centre (CEBAS) (http:/ / www.cebas.csic.es/general_spain/ionomica.html (accessed on 15 February 2020)) in order to determine the total content of each element from the samples of each location. The method used was based on the measurement of atomic emission using plasma spectroscopy (IPC-OES) [69]. Thus, the following elements were analysed using this technique: $\mathrm{Al}, \mathrm{As}, \mathrm{B}, \mathrm{Be}, \mathrm{Bi}, \mathrm{Ca}, \mathrm{Cd}, \mathrm{Co}, \mathrm{Cr}, \mathrm{Cu}, \mathrm{Fe}, \mathrm{K}, \mathrm{La}$, Li, $\mathrm{Mg}, \mathrm{Mn}, \mathrm{Mo}, \mathrm{Na}, \mathrm{Ni}, \mathrm{P}, \mathrm{Pb}, \mathrm{Rb}, \mathrm{S}, \mathrm{Sb}, \mathrm{Se}, \mathrm{Si}, \mathrm{Sr}, \mathrm{Ti}, \mathrm{Tl}, \mathrm{V}, \mathrm{Zn}$. In addition, by means of an Elemental Analyser, total $\mathrm{C}$ and total $\mathrm{N}$ were calculated. The results for macroelements were expressed in \% dry weight (g/100 g), and for microelements in ppm (mg/kg). However, 
concentrations of some elements were very low, under the limit established for their detection, and were therefore excluded from the analysis' results.

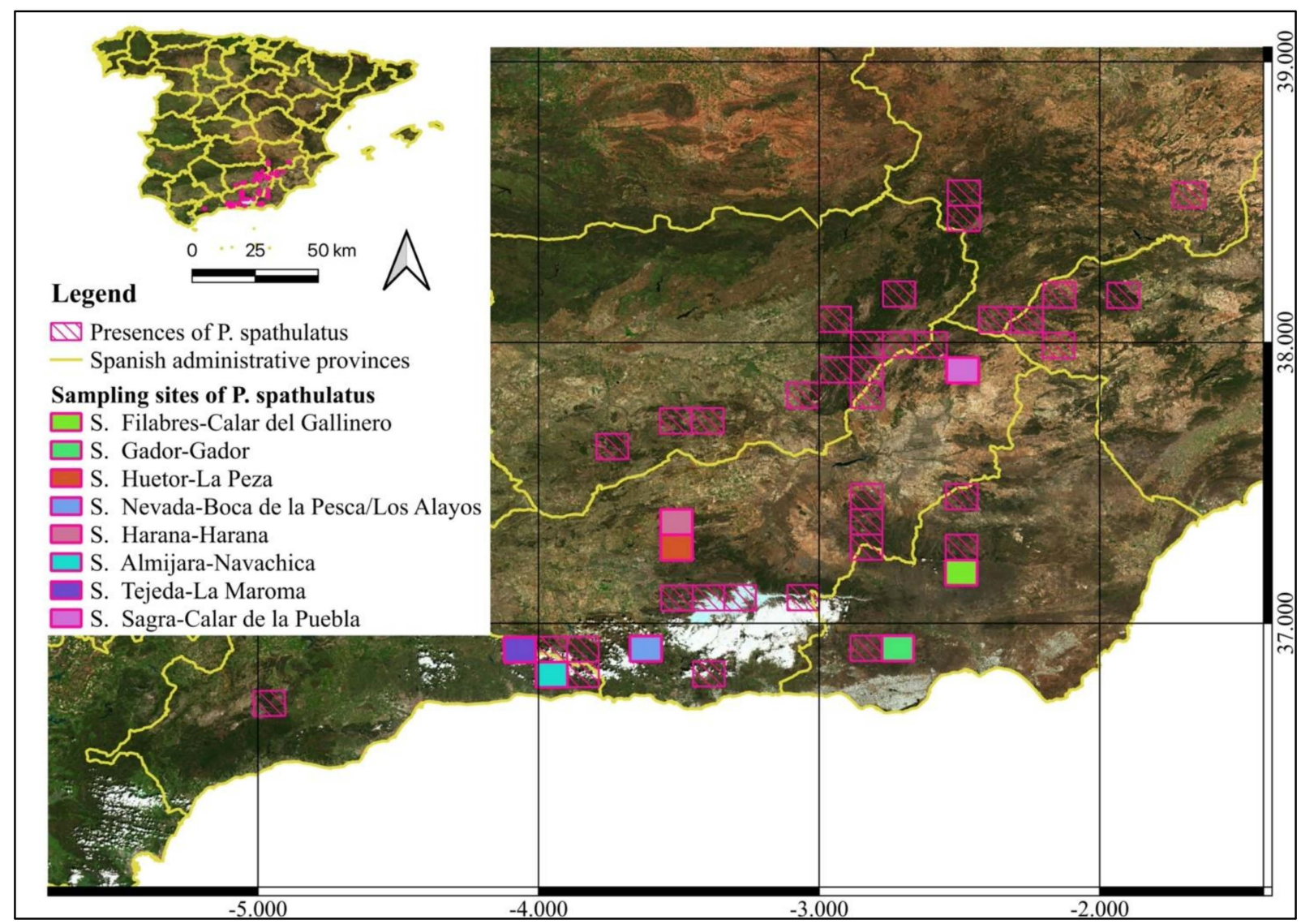

Figure 3. Location of the study area and sampling sites of P. spathulatus, pink grids indicate the presence of this species and solid-coloured grids the sampling locations.

\subsubsection{Analysis of the Phytoavailable Soil Elements}

Different methods exist for the extraction of phytoavailable elements, but none of them is established as a standard. Abedin et al. [70] evaluated several simple extraction methods to assess the availability of potentially phytotoxic metals and nutrients in soils, and thus relate them to their concentration in plant tissues. Quevauviller et al. [71] proposed extraction by $0.05 \mathrm{M}$ and $0.025 \mathrm{M}$ ammonium EDTA, observing that the best results for the extraction of heavy metals were obtained with the former. Therefore, the method used in this work was ammonium EDTA $(0.05 \mathrm{M})$, chosen because of its favourable characteristics and because it is an extraction method with good results in basic soils such as dolomite. However, it should be borne in mind that the phytoavailable elements found are only in relation to the method used, and that, in reality, there is no single method that homogeneously extracts all ions. Once the phytoavailable contents of the elements were extracted, they were sent to the ionomics service of CEBAS for analysis.

\subsection{Analysis of Plant Tissues}

Samples of plant tissues from 25 specimens were collected for each locality separately. Each sample contained $5 \mathrm{~g}$ of material in fresh weight, so that at least $2 \mathrm{~g}$ in dry weight were obtained when dried. In the laboratory, leaves, stems and roots were separated, and washed with plenty of distilled water to remove any residue; their fresh weight was determined, and afterwards, they were dried and reweighed. They were dried in an oven (Binder ED 115) at $70{ }^{\circ} \mathrm{C}$ with aeration, until weight stabilisation, and the dry weight of the 
sample was established. Tissues were ground in a mixer mill for one minute. Finally, $1 \mathrm{~g}$ of these samples was sent to the Ionomics Laboratory of CEBAS for their analysis, as in the case of soil and phytoavailable samples. The rest of the material is stored at the University of Almeria.

\subsection{Calculation of BCF and TF Parameters}

The efficiency of a species to be used as a bioindicator can be estimated by the Bioconcentration Factor (BCF) and the Translocation Factor (TF) [64]. The BCF is defined as the total element concentration in the shoot tissue divided by its concentration in the soil. By comparison, TF indicates the mobility of an element within plants, and is defined as the total concentration of each element in the shoot tissue divided by its total concentration in the roots. When BCF $>1$, the plant species can be defined as an accumulator, and if $\mathrm{TF}>1$, it is able to concentrate metals in the aerial parts, from which they can be easily removed (phytoextraction) [65]. A plant can be considered as a bioindicator of an element when its internal concentration reflects the concentration in soils [66].

The bioindicator potential of P. spathulatus was determined by both BCF (Equation (1)) and TF (Equation (2)). For this purpose, the average values of the BCFs obtained for each locality were determined, relating the mineral contents of the foliar samples to the contents of the soil samples, and the average values of the TFs, relating the mineral contents of the foliar samples and the root samples. It is worth noting that for the phytoavailable elements in the soil, the ratio $(\mathrm{mg} / \mathrm{kg}) /(\mathrm{mg} / \mathrm{L})$ was used; therefore, a corresponding transformation of units had to be made. In addition, the ratio between the contents of the foliar/stem samples, and between the root/stem samples was also calculated.

$$
\mathrm{BCF}=\frac{\text { Concentration of elements in sprout tissue }\left(\frac{\mathrm{mg}}{\mathrm{kg}}\right)}{\text { Soil element concentration }\left(\frac{\mathrm{mg}}{\mathrm{kg}}\right)}
$$

Equation (1). Equation for obtaining the Bioconcentration Factor (BCF).

$$
\mathrm{TF}=\frac{\text { Concentration of elements in sprout tissue }\left(\frac{\mathrm{mg}}{\mathrm{kg}}\right)}{\text { Concentration of elements in the root tissue }\left(\frac{\mathrm{mg}}{\mathrm{kg}}\right)}
$$

Equation (2). Equation for obtaining the Translocation Factor (TF).

\subsection{P. spathulatus Plant Communities}

In the field, a vegetation relevé (field inventory) was sampled and associated with each soil-plant tissue sample. These vegetation surveys recorded all the species' presences, together with an estimate of their abundance, in a $5 \mathrm{~m}^{2}$ plot (Table S2). Different ecological indices (Taxa_S; Individuals (vegetation cover); Dominance_D; Simpson_1-D; Shannon_H; Evenness_e^H/S; Menhinick; Margalef; Equitability_J) were calculated using PAST software version 4.08 [72]. These indices were correlated with the total and phytoavailable contents of the soils to try to reveal possible relationships that may help to understand the structure and characteristics of these unique plant communities.

\subsection{Data Analysis}

For the study of the correlations between the different mineral contents, the SPSS software version 26.0 [73] was used. Through this programme, bivariate correlations were carried out, which highlighted as significant those that obtained results of $p<0.05$ and $p<0.01$, both positive and negative. In this way, the correlations between the different contents (foliar-total, foliar-available, total-available, total-available, etc.) could be checked. In addition, PAST 4 software was used to calculate the different richness and diversity indices. The data obtained were used to determine the different relationships between the 
plant communities inhabiting the dolomite soils. These correlations were also confirmed using SPSS 26.0 software.

\section{Results and Discussion}

\subsection{Analysis of the Mineral Contents of Soil Samples}

\subsubsection{Total Elements}

Table 2 shows the element contents obtained from the analysis of soil samples. These elements, mainly known as macroelements (or macronutrients), can be divided into primary $(\mathrm{N}, \mathrm{P}$ and $\mathrm{K})$ and secondary $(\mathrm{Ca}, \mathrm{Mg}$ and $\mathrm{S})$. The highest values were for $\mathrm{C}$, followed by $\mathrm{Ca}$ and $\mathrm{Mg}$. This was to be expected, due to the chemical nature of the soil, composed of carbonate rocks $\left(\mathrm{CaMg}\left(\mathrm{CO}_{3}\right)_{2}\right)$. Thus, high $\mathrm{Ca}$ and $\mathrm{Mg}$ concentrations may limit plant growth in this type of soil. With respect to the rest of the elements analysed, low N, P and $\mathrm{K}$ contents were observed, which are also typical of these soils and may be related to the specificity of the dolomitic flora [14]. The highest values for $\mathrm{N}$ and $\mathrm{K}$ were found at GAL, corresponding to Calar del Gallinero, and GAD (Sierra de Gador), the latter with the lowest values for $\mathrm{C}$. In all cases, $\mathrm{Ca}$ concentrations were more abundant than $\mathrm{Mg}$, and the values found here are very close to those found in previous research [14].

In the case of the essential microelements, Fe and Mn stood out for their high values, with large concentrations in all the locations studied, especially in GAL and GAD. Because these alkaline earth metals are found in such high concentrations in these soils, they can be considered as heavy metals and, therefore, cause toxicity problems in plants. GAD also showed higher values than other sites for several essential micronutrients such as $\mathrm{B}, \mathrm{Cu}$, $\mathrm{Ni}$ and $\mathrm{Zn}$, followed by GAL. This is also the case for other elements and heavy metals such as $\mathrm{Cr}, \mathrm{Pb}, \mathrm{Si}$ and $\mathrm{Tl}$. Elements such as $\mathrm{Ni}$ and $\mathrm{Pb}$ may appear in high concentrations due to the weathering of the source rock. Other elements, such as $\mathrm{Cr}$ or $\mathrm{Cu}$ often appear as a result of human activities in these areas. Si contents may be due to Si being present in the source rock. In this context, the localities GAL and GAD are worth mentioning, which showed the highest values for most of the mentioned micronutrients and heavy metals. In fact, GAD has been a mining area since Roman times precisely due to being an interesting area for the extraction of metals ( $\mathrm{Pb}, \mathrm{Fe}$, etc.) [74]. In the case of GAL in the Sierra de los Filabres, there was also mining activity of Fe extraction.

\subsubsection{Phytoavailable Elements}

Values obtained for the phytoavailable macronutrients generally followed the same trend as the total contents. $\mathrm{N}$ and $\mathrm{C}$ were not analysed in this case because they are part of the extraction reagents. High concentrations of $\mathrm{Ca}$ and $\mathrm{Mg}$ were found, especially of the former, due to the composition of the soil on which the plant species grows. $\mathrm{P}$ and $\mathrm{K}$ contents were low in these soils, both in total and phytoavailable contents, but with small differences between localities. Table 3 shows the values obtained for essential macronutrients, micronutrients and other plant-available elements of interest.

It was found (unpublished data) that some positive correlation was discovered between $\mathrm{Ca}$ and $\mathrm{S}$ found in the soil in plant-available form, although neither was correlated with plant-available Mg. In this sense, it can be justified that, in most locations, when the Ca value increased, the $S$ value also increased, and vice versa. With regard to $P$, although it is essential for the formation of nucleic acids and helps in the transport of energy, it tends to precipitate easily, which is why the availability of this element in soils is usually low [75]. The fact that $P$ is, of all the macronutrients, the one with the lowest values is one more indication of its fundamental role in explaining the limitations that certain peculiar rocks impose on vegetation [4]. 


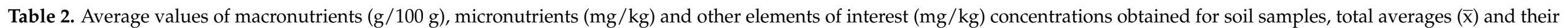
standard deviations (SD) for each element.

\begin{tabular}{|c|c|c|c|c|c|c|c|c|c|c|c|c|c|c|c|c|c|c|c|}
\hline & \multicolumn{8}{|c|}{ Macronutrients (g/100 g) } & \multicolumn{7}{|c|}{ Micronutrients (mg/kg) } & \multicolumn{4}{|c|}{ Other Elements (mg/kg) } \\
\hline & $\mathrm{C}$ & $\mathbf{N}$ & $\mathrm{Ca}$ & $\mathbf{K}$ & $\mathrm{Mg}$ & $\mathbf{P}$ & $S$ & B & $\mathrm{Cu}$ & $\mathrm{Fe}$ & Mn & Mo & $\mathbf{N i}$ & $\mathrm{Zn}$ & Al & $\mathrm{Cr}$ & $\mathrm{Pb}$ & $\mathrm{Si}$ & $\mathrm{Tl}$ \\
\hline MAR & 14.32 & 0.21 & 19.57 & 0.14 & 11.49 & 0.04 & 0.16 & 2.68 & 3.61 & 3702.39 & 708.05 & 0.44 & 4.08 & 24.92 & 0.63 & 20.25 & 20.11 & 163.66 & 9.85 \\
\hline GAL & 13.13 & 0.39 & 15.05 & 0.47 & 8.75 & 0.05 & 0.16 & 11.60 & 10.95 & $15,290.77$ & 1183.68 & 2.31 & 10.13 & 41.13 & 2.04 & 31.01 & 42.71 & 533.96 & 14.23 \\
\hline $\mathrm{BOC}$ & 13.45 & 0.06 & 21.54 & 0.08 & 14.07 & 0.01 & 0.16 & 1.09 & 1.70 & 1247.20 & 697.25 & 1.60 & 2.26 & 34.01 & 0.23 & 6.03 & 24.67 & 126.32 & 7.44 \\
\hline PEZ & 13.57 & 0.05 & 21.31 & 0.07 & 13.22 & 0.01 & 0.16 & 0.29 & 1.33 & 1009.78 & 682.71 & 2.24 & 1.54 & 8.80 & 0.19 & 4.64 & 7.75 & 129.76 & 7.46 \\
\hline ALA & 12.97 & 0.08 & 21.08 & 0.08 & 13.19 & 0.01 & 0.16 & 0.90 & 1.85 & 1446.81 & 713.33 & 0.73 & 2.09 & 26.77 & 0.28 & 13.21 & 11.51 & 247.00 & 8.22 \\
\hline GAD & 10.28 & 0.22 & 13.20 & 0.66 & 7.47 & 0.05 & 0.15 & 19.45 & 52.82 & $26,207.33$ & 2029.63 & 1.90 & 14.36 & 236.86 & 2.40 & 37.79 & 410.92 & 526.98 & 18.18 \\
\hline NAV & 13.63 & 0.06 & 20.61 & 0.05 & 12.75 & 0.01 & 0.16 & 0.00 & 0.99 & 915.32 & 720.44 & 0.88 & 1.47 & 16.38 & 0.17 & 5.45 & 9.26 & 131.66 & 7.59 \\
\hline PUE & 13.84 & 0.23 & 19.29 & 0.20 & 9.09 & 0.02 & 0.19 & 6.76 & 3.84 & 3936.07 & 610.54 & 0.22 & 5.04 & 20.84 & 0.79 & 16.93 & 20.64 & 424.17 & 10.07 \\
\hline $\bar{x}$ & 13.22 & 0.16 & 18.91 & 0.20 & 11.16 & 0.02 & 0.16 & 5.02 & 8.72 & 6078.14 & 889.33 & 1.17 & 4.72 & 46.08 & 0.77 & 15.74 & 61.12 & 272.05 & 10.07 \\
\hline SD & 1.17 & 0.11 & 2.93 & 0.21 & 2.34 & 0.02 & 0.01 & 6.58 & 16.82 & 8829.94 & 459.61 & 0.85 & 4.56 & 72.44 & 0.86 & 12.03 & 131.71 & 173.84 & 3.75 \\
\hline
\end{tabular}

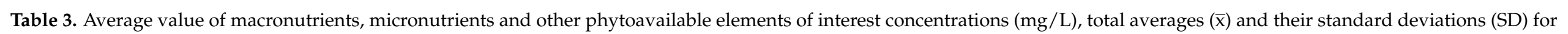
each element.

\begin{tabular}{|c|c|c|c|c|c|c|c|c|c|c|c|}
\hline & \multicolumn{5}{|c|}{ Macronutrients $(\mathrm{mg} / \mathrm{L})$} & \multicolumn{3}{|c|}{ Micronutrients (mg/L) } & \multicolumn{3}{|c|}{ Other Elements (mg/L) } \\
\hline & $\mathrm{Ca}$ & $\mathbf{K}$ & $\mathrm{Mg}$ & $\mathbf{P}$ & S & $\mathbf{F e}$ & Mn & $\mathrm{Zn}$ & Al & $\mathrm{Pb}$ & $\mathrm{Si}$ \\
\hline MAR & 1391.90 & 16.47 & 507.10 & 3.86 & 15.77 & 10.18 & 6.95 & 0.53 & 12.41 & 1.13 & 10.31 \\
\hline GAL & 1487.25 & 37.92 & 295.00 & 4.55 & 19.83 & 14.57 & 20.15 & 0.43 & 16.32 & 1.29 & 13.56 \\
\hline BOC & 1081.00 & 10.35 & 494.85 & 1.37 & 16.99 & 3.74 & 4.37 & 0.80 & 5.02 & 0.71 & 5.36 \\
\hline PEZ & 1897.12 & 19.76 & 893.60 & 2.94 & 21.28 & 9.21 & 8.05 & 0.32 & 11.48 & 0.86 & 12.56 \\
\hline ALA & 2217.35 & 23.22 & 979.40 & 2.74 & 22.34 & 8.26 & 9.15 & 1.03 & 12.56 & 1.14 & 12.93 \\
\hline GAD & 792.83 & 28.26 & 291.70 & 2.20 & 13.77 & 14.28 & 23.30 & 1.58 & 13.23 & 20.65 & 7.25 \\
\hline NAV & 2378.25 & 24.05 & 844.60 & 3.27 & 28.24 & 11.21 & 9.84 & 0.56 & 16.69 & 0.78 & 11.31 \\
\hline PUE & 1455.07 & 18.86 & 283.97 & 2.94 & 17.97 & 12.02 & 4.08 & 0.24 & 12.53 & 0.80 & 9.06 \\
\hline HAR & 1051.55 & 9.07 & 455.35 & 1.66 & 12.91 & 3.56 & 4.26 & 0.11 & 4.97 & 0.10 & 4.59 \\
\hline $\bar{x}$ & 1528.03 & 20.88 & 560.62 & 2.84 & 18.79 & 9.67 & 10.02 & 0.62 & 11.69 & 3.05 & 9.66 \\
\hline SD & 539.35 & 8.91 & 274.90 & 1.01 & 4.77 & 4.00 & 7.01 & 0.46 & 4.19 & 6.61 & 3.31 \\
\hline
\end{tabular}


The phytoavailable contents of the main essential microelements and other elements of interest were also analysed. The values obtained for most of these elements were very close to zero, thus only those with appreciable values are presented here (Table 3). This may be due to the fact that they are usually very scarce in soils, or to the extraction method. In this case, similar proportions to those obtained for total elements were also found in the different localities. With the extraction method used, the highest concentrations were observed for Fe and $\mathrm{Mn}$, in addition to $\mathrm{Al}$ and $\mathrm{Si}$, and a high $\mathrm{Pb}$ content in GAD. In this sense, it is interesting to note that the presence of Fe and $\mathrm{Al}$ oxides in soils has favourable effects on the availability of other elements such as $\mathrm{P}$, and can also improve some physical properties of the soil, increasing aggregate stability, permeability, friability, porosity and hydraulic conductivity [76].

\subsection{Analysis of Foliar Mineral Contents}

Table 4 shows the concentrations of the main macroelements mentioned above, obtained from the foliar samples. Observing the table, it can be seen from the low deviations found between the data that this species has a fairly stable leaf ionomic composition, regardless of the location sampled. As differences, low $\mathrm{C}$ and higher $\mathrm{Mg}$ contents of the leaves of the samples from ALA can be highlighted.

Table 4. Average values in foliar samples of macronutrients ( $\mathrm{g} / 100 \mathrm{~g})$, essential microelements $(\mathrm{mg} / \mathrm{kg})$ and other elements of interest $(\mathrm{mg} / \mathrm{kg})$ concentrations, total averages $(\overline{\mathrm{x}})$ and their standard deviations (SD) for each element.

\begin{tabular}{|c|c|c|c|c|c|c|c|c|c|c|c|c|c|c|c|c|}
\hline & \multicolumn{7}{|c|}{ Macronutrients (g/100 g) } & \multicolumn{5}{|c|}{ Micronutrients (mg/kg) } & \multicolumn{4}{|c|}{ Other Elements (mg/kg) } \\
\hline & C & $\mathbf{N}$ & $\mathrm{Ca}$ & K & Mg & $\mathbf{P}$ & $S$ & B & $\mathrm{Cu}$ & $\mathrm{Fe}$ & Mn & $\mathrm{Zn}$ & Al & $\mathrm{Cr}$ & $\mathrm{Pb}$ & Tl \\
\hline MAR & 44.15 & 1.46 & 1.65 & 0.47 & 0.54 & 0.06 & 0.11 & 17.35 & 4.46 & 73.66 & 39.39 & 13.98 & 62.98 & 1.33 & 1.20 & 18.42 \\
\hline GAL & 44.70 & 1.33 & 1.13 & 0.67 & 0.22 & 0.04 & 0.09 & 17.27 & 2.60 & 58.15 & 24.14 & 13.84 & 57.31 & 0.18 & 0.64 & 0.64 \\
\hline BOC & 44.81 & 1.56 & 1.15 & 1.10 & 0.23 & 0.07 & 0.10 & 16.00 & 6.22 & 140.01 & 63.67 & 22.88 & 116.25 & 0.34 & 5.68 & 0.57 \\
\hline PEZ & 44.34 & 1.50 & 1.40 & 0.80 & 0.24 & 0.05 & 0.13 & 16.01 & 4.16 & 117.07 & 50.47 & 13.09 & 111.54 & 0.40 & 0.99 & 2.59 \\
\hline ALA & 42.25 & 1.30 & 1.45 & 0.64 & 0.67 & 0.05 & 0.11 & 15.32 & 3.83 & 722.50 & 67.84 & 11.56 & 780.95 & 10.53 & 2.45 & 110.80 \\
\hline GAD & 44.57 & 1.57 & 0.83 & 0.83 & 0.23 & 0.05 & 0.09 & 11.92 & 3.66 & 39.64 & 20.70 & 16.32 & 32.50 & 0.19 & 0.56 & 2.68 \\
\hline NAV & 45.29 & 1.84 & 1.09 & 0.64 & 0.36 & 0.09 & 0.14 & 9.72 & 2.94 & 77.04 & 34.86 & 17.65 & 69.78 & 0.16 & 0.69 & 9.30 \\
\hline PUE & 44.49 & 1.48 & 1.47 & 0.94 & 0.49 & 0.07 & 0.11 & 11.56 & 2.70 & 90.11 & 50.53 & 19.77 & 104.71 & 0.71 & 1.25 & 15.22 \\
\hline HAR & 44.40 & 1.32 & 1.38 & 0.60 & 0.47 & 0.06 & 0.09 & 18.10 & 3.71 & 60.48 & 33.88 & 8.07 & 56.54 & 0.65 & 0.75 & 11.80 \\
\hline $\bar{x}$ & 44.33 & 1.48 & 1.28 & 0.74 & 0.38 & 0.06 & 0.11 & 14.81 & 3.81 & 153.18 & 42.83 & 15.24 & 154.73 & 1.61 & 1.58 & 19.11 \\
\hline SD & 0.85 & 0.17 & 0.25 & 0.19 & 0.17 & 0.01 & 0.02 & 2.99 & 1.11 & 215.70 & 16.48 & 4.46 & 236.57 & 3.36 & 1.64 & 35.00 \\
\hline
\end{tabular}

Regarding essential microelements and other notable elements, zero values were obtained for most locations for the elements $\mathrm{Cd}, \mathrm{Co}$ and Mo. The highest metal concentrations were observed for $\mathrm{Fe}, \mathrm{Mn}$ and $\mathrm{Al}$, followed by $\mathrm{B}, \mathrm{Tl}$ and $\mathrm{Zn}$. In addition, notably high concentrations of $\mathrm{Fe}$ and $\mathrm{Mn}$, and of $\mathrm{Al}$ and $\mathrm{Tl}$, were found at ALA, whose total and phytoavailable contents in soils were the lowest.

Table 5 shows that there were no correlations between the same element in leaves and soil, except for Mn. Foliar Ca correlated with total soil C and with microelements such as $\mathrm{Cu}, \mathrm{Fe}, \mathrm{Mn}, \mathrm{Zn}$ and $\mathrm{Pb}$. Foliar $\mathrm{S}$ correlated with other macronutrients such as $\mathrm{Ca}, \mathrm{K}, \mathrm{Mg}$ and $\mathrm{P}$ from the total soil contents, and with microelements like B and Cr. Foliar Mn was positively or negatively correlated with macroelements and some essential microelements $(\mathrm{B}, \mathrm{Fe})$ and with $\mathrm{Al}$ and $\mathrm{Tl}$.

Table 5. Correlating elements between leaf and total soil contents (Pearson's correlation coefficients). * Higher correlations. (f: foliar; s: soil).

\begin{tabular}{|c|c|c|c|c|c|c|c|c|c|c|c|c|c|c|}
\hline Foli & $1 \mathrm{C} \_s$ & a_s & s & Ig_s & s & $\mathrm{s}$ & $s$ & e_s & s & s & s & s & b_s & I1_s \\
\hline Ca_f & 0.76 & 58 & & & & & -0.6 & $*$ & $*$ & & & -0.409 & $\underset{*}{-0.696}$ & 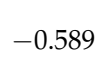 \\
\hline$S$ & 0.472 & $\begin{array}{c}0.741 \\
*\end{array}$ & $-\underset{*}{-0.682}$ & & $\underset{*}{-0.667}$ & $\underset{*}{-0.707}$ & & -0.649 & & & $\underset{*}{-0.692}$ & $-\underset{*}{0.695}$ & & -0.6 \\
\hline Mn_f & 0.395 & $\begin{array}{c}0.820 \\
*\end{array}$ & $\underset{*}{-0.670}$ & 0.748 * & $\underset{*}{-0.701}$ & $\underset{*}{-0.667}$ & -0.579 & $\underset{*}{-0.682}$ & -0.641 & -0.489 & $\underset{*}{-0.687}$ & -0.608 & -0.520 & $\begin{array}{c}-0.677 \\
*\end{array}$ \\
\hline
\end{tabular}




\subsection{Analysis of BCF and TF Parameters}

\subsubsection{BCF Values Assessment}

BCFs were derived for both total soil and phytoavailable contents. In this respect, there is no general agreement among researchers on the use of total soil contents to assess the phytoremediation potential of a given species. As a result, there is considerable uncertainty when calculating BCF. For example, Baker et al. [77] considered the total soil element concentration to calculate it, whereas Poschenrieder et al. [78] considered the EDTA soil extractable element concentration, i.e., the same extraction performed in the present study. However, according to Buscaroli [65] it is preferable to use the phytoavailable fraction to evaluate the phytoremediation capacity. In this study the authors compared the results obtained for both contents.

With regard to the results derived from the total soil contents, BCF values obtained for all the elements are shown in Figure 4. Although values $>1$ already indicate accumulation [65], to determine the possible use of this species in phytoremediation techniques, values $>10$ are interesting as they would indicate hyperaccumulation. It is possible to observe the elements with an average BCF value higher than 1 for all locations; thus, the plant would have the potential to accumulate those. The values $>1$ for $C, N, K$ and $\mathrm{P}$ were to be expected as these are essential macronutrients for all organisms, although the last three are found in low proportion in the soils, especially in dolomite and other unusual soils [13]. Furthermore, the high values for these essential macronutrients can be considered regular, as plants tend to accumulate reserves of them [75]; for example, BCF $>10$ obtained for $\mathrm{N}$. However, the fact that they have values $<1$ does not mean that they are deficient, but that they do not accumulate them in relation to their soil content. It is possible that this may happen precisely because their contents in the soil are very high, not because of accumulation.

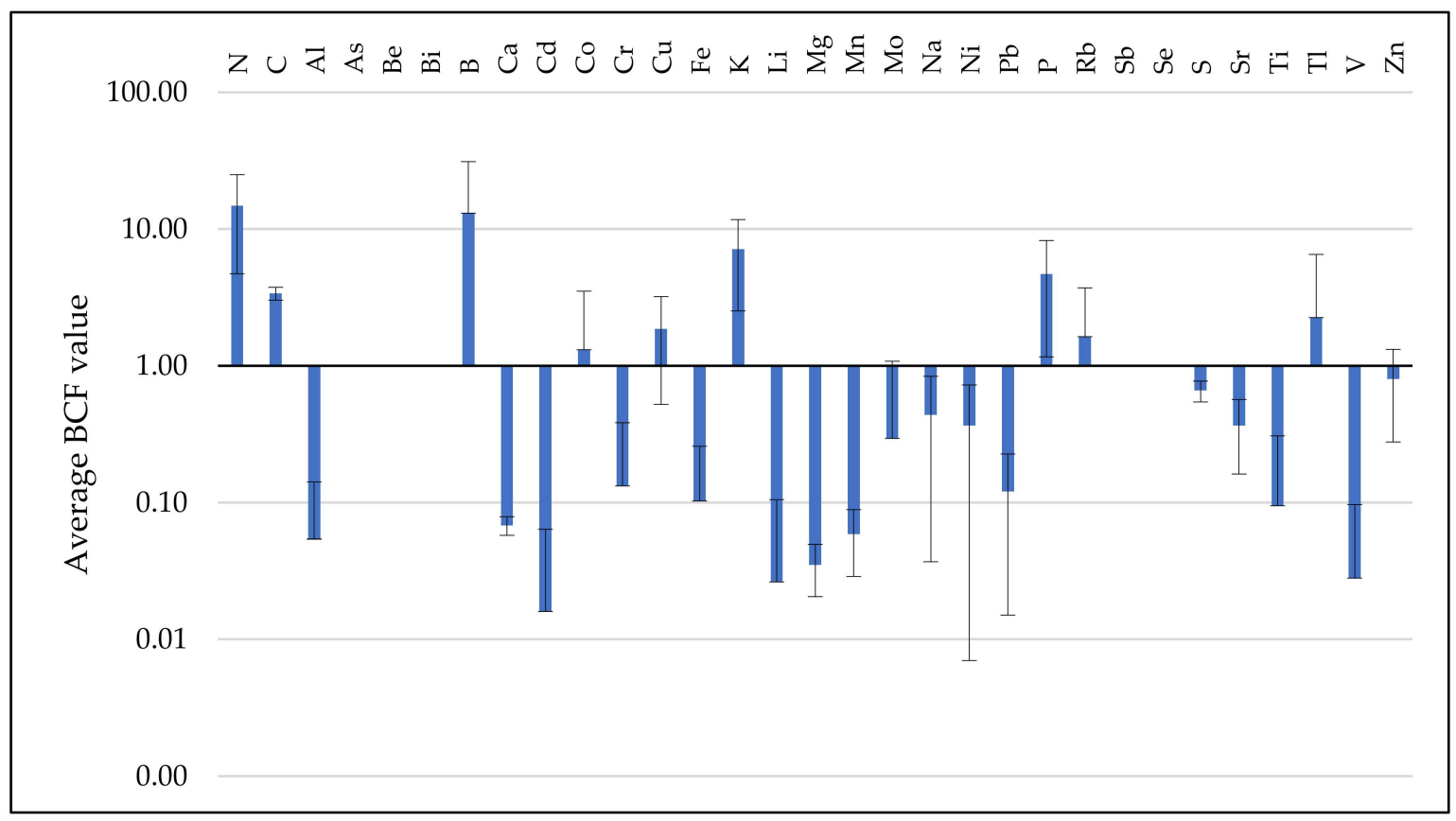

Figure 4. Average values of $\mathrm{BCFs}$, and their corresponding standard deviations, obtained from the total elements.

In contrast, the high BCF of B (>10) was noteworthy. This element is also essential for plant growth [79]. However, a high concentration of this element in the soil can cause toxic effects in plants [80]. Therefore, for a plant to be able to accumulate B in its tissues, it must be highly tolerant to it. In this sense, as the plant species studied has a very high bioaccumulation factor, it is assumed that it will show this tolerance and, therefore, will be able to eliminate toxic concentrations of B in the soil. In relation to this element, a species 
growing on gypsum, Gypsophila sphaerocephala Fenzl ex Tchihat., is known to be able to tolerate high concentrations of B in soil [81]. Given the similarities in the composition of both substrates, this theory could be corroborated in the dolomite flora. Furthermore, the ability to accumulate $\mathrm{Tl}$ and $\mathrm{Rb}$ (although $<10$ ) was also remarkable. This element, although largely unknown, is considered dangerous to living beings, causing both acute and chronic toxic effects $[82,83]$. Tl contamination in soils is increasing, mainly due to industrial activities such as mining, smelting of Tl-rich ores and metallurgical production [84-86]. In this sense, the fact that the species has the potential to accumulate Tl may represent a breakthrough in the phytoremediation field.

Regarding the results obtained from the phytoavailable contents present in the soil, the values obtained for the BCF are shown in Figure 5. As in the previous case, there were high $\mathrm{BCF}$ values $(\mathrm{BCF}>10)$ for $\mathrm{K}$ and $\mathrm{P}$, and the aforementioned $\mathrm{B}$ and $\mathrm{Tl}$, which, in this case, resulted in higher values. Thus, the high $\mathrm{BCF}$ values for these elements indicate that the plant is capable of hyperaccumulating these elements. Regarding the remainder of the values obtained, there were those that, with respect to the totals, had values lower than 1 , including essential macronutrients (e.g., S) and micronutrients $(\mathrm{Cu}, \mathrm{Fe}, \mathrm{Ni}$ and $\mathrm{Zn})$, and others beneficial or not ( $\mathrm{Al}, \mathrm{Cr}, \mathrm{Rb}$ and $\mathrm{Ti})$. $\mathrm{Cr}$ is an essential trace element in the metabolism of animals and humans [87], but its high presence in the soil is toxic to animals, potentially inducing cancer and teratism [88]. At present, $\mathrm{Cr}$ (IV) is considered to be one of the major pollutants, but no cost-effective and efficient remedies have been found to remediate $\mathrm{Cr}$ (IV) contamination [89]. Therefore, if this species is able to hyperaccumulate $\mathrm{Cr}$, it could contribute to the progress of studies currently underway to solve this problem. These results may indicate that the plant-available fraction of the soil best explains the plant's foliar ionic composition.

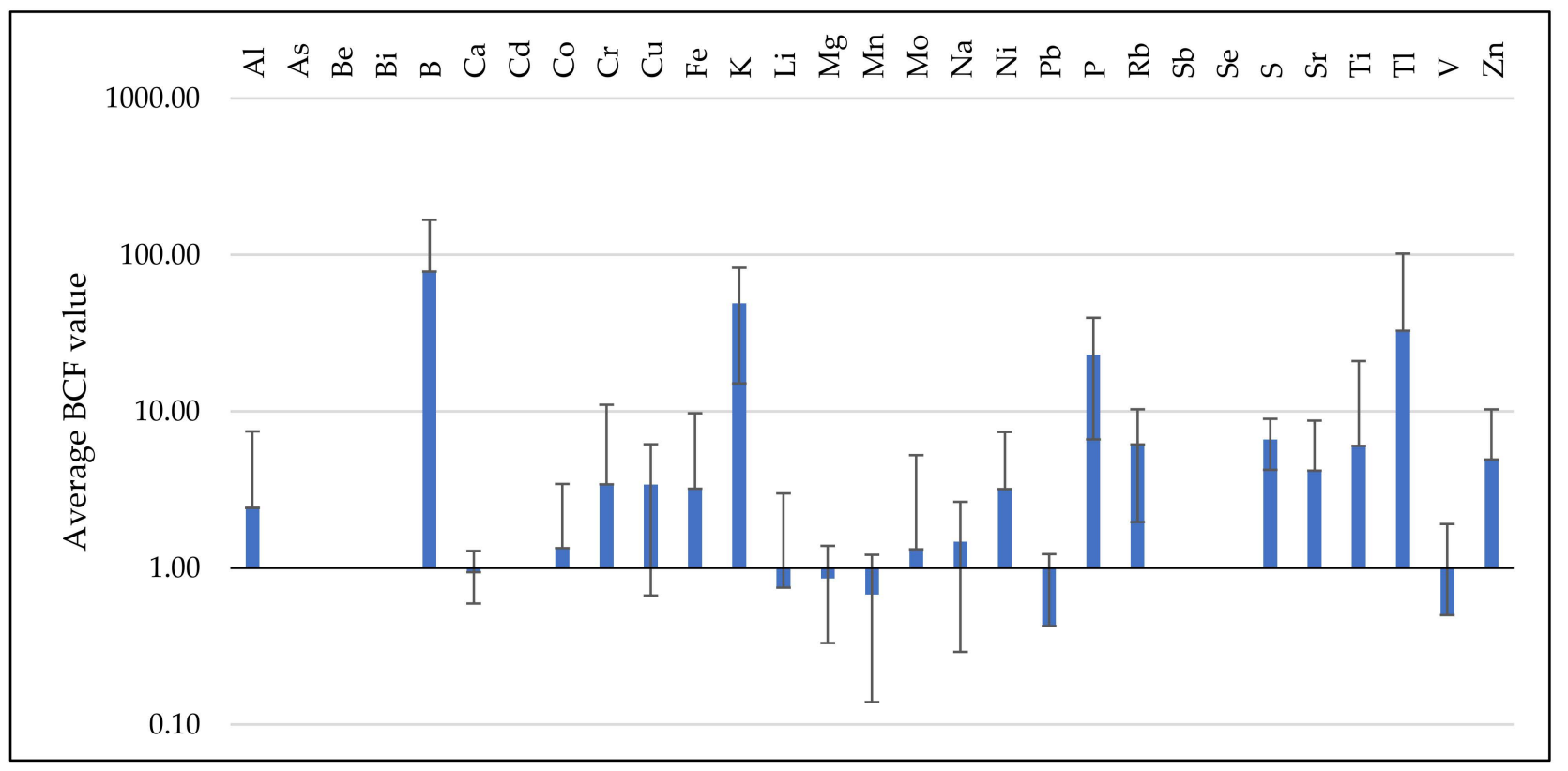

Figure 5. Average values of BCFs, and their corresponding standard deviations, obtained from the available elements.

There are some hypotheses stating that toxic metal-accumulating species may employ this technique as a protective measure against herbivores $[90,91]$ and pathogens $[92,93]$.

\subsubsection{TF Values Assessment}

In order to assess the ability of $P$. spathulatus to transfer metals from the roots to its aerial tissues and, thus, to be used in phytoextraction or phytostabilisation processes, the Translocation Factor (TF) was calculated as the ratios of leaf-to-root, leaf-to-stem and stem-to-root (Figure 6). Only vegetal tissues data were used for this factor. 


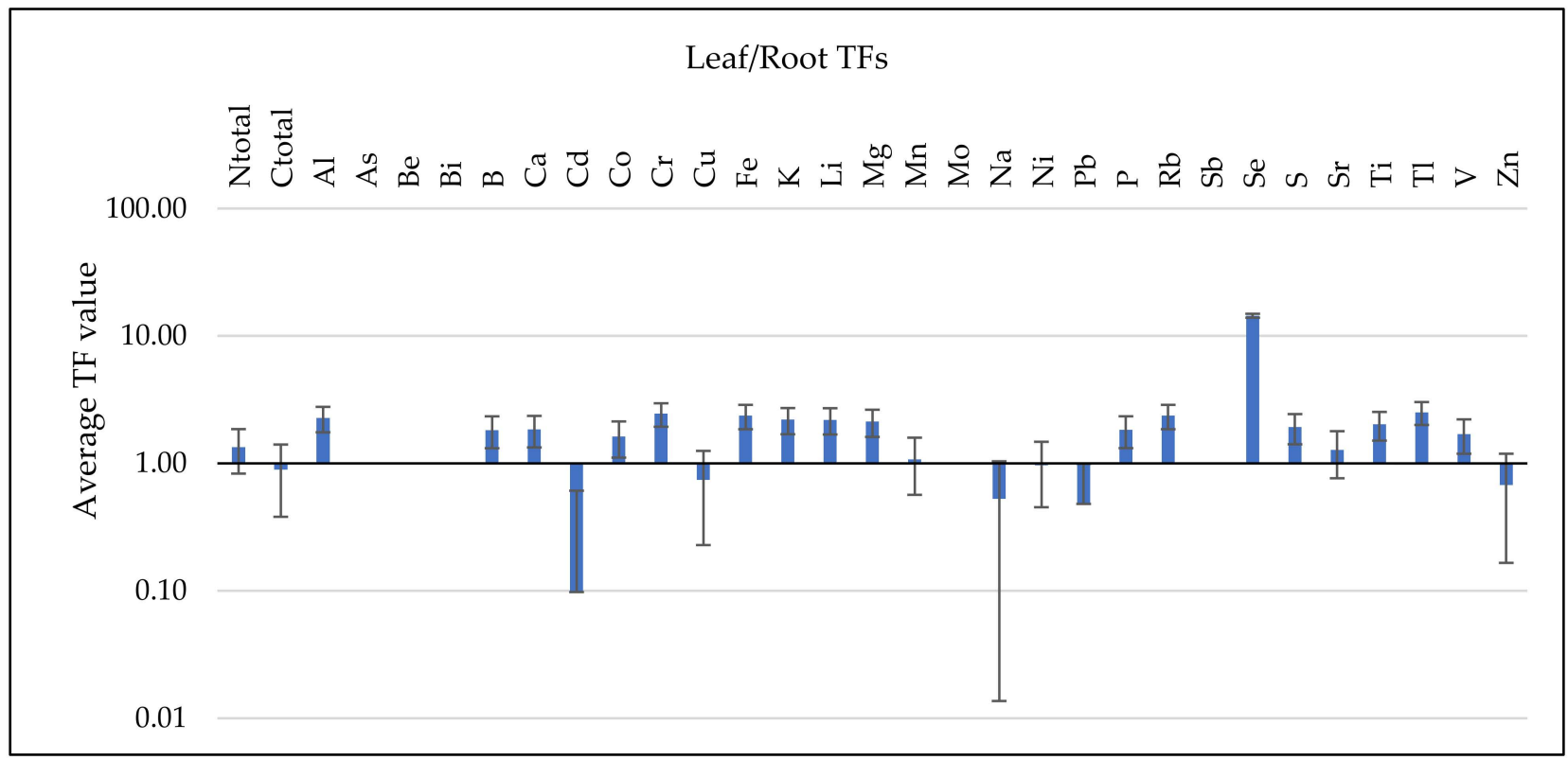

(a)

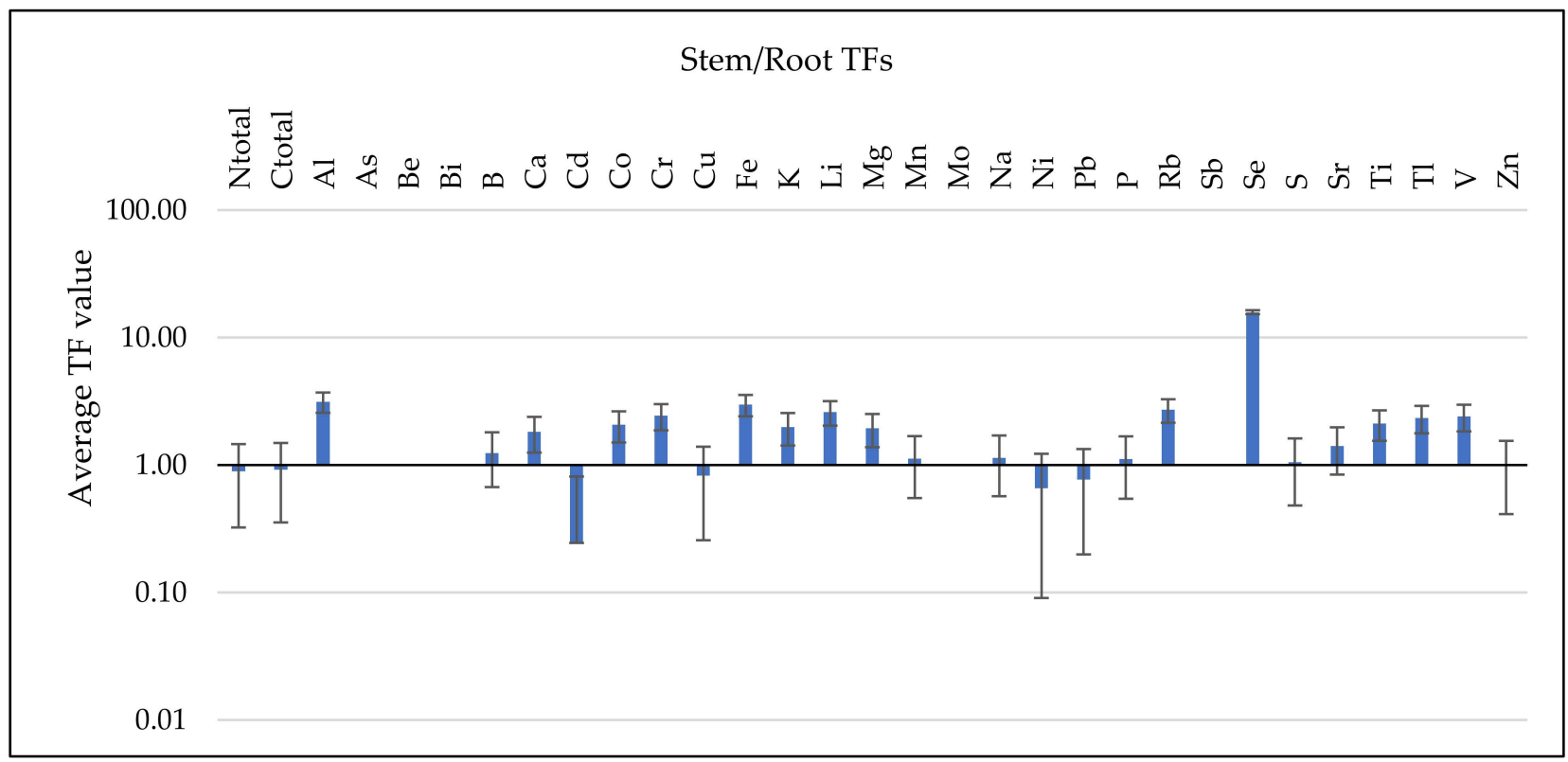

(b)

Figure 6. Average TF values obtained from the relationship between the mineral contents of leaves, stems and roots for each element studied for all localities. (a) Leaf/Root TFs. (b) Stem/Root TFs. Data plotted on log base 10 scale.

TFs obtained with a value $>1$ represent those elements with good mobility within the plant. The elements are transported from the roots to the stem tissues of the plant via xylem and from there they can then be incorporated into the trophic chains, or removed by different techniques. If the TF $>1$ values for leaves and stems are added up, it can be seen that most of the elements studied accumulate in the aerial part of the plant, with the exception of $\mathrm{Cd}, \mathrm{Pb}$ and $\mathrm{Zn}$ (Figure $6 \mathrm{a}, \mathrm{c}$ ). For example, TF $>1$ was obtained for the Leaf/Root ratio (Figure 6a) for N, Al, B, Ca, Co, Cr, Fe, K, Li, Mg, Mn, P, Rb, Se, S, Sr, Ti, Tl and $\mathrm{V}$. It is worth highlighting the presence of $\mathrm{B}$ in the leaves, whose main function is the formation of the cell wall during cell divisions, which promotes faster organ growth [75].

If the essential macronutrients and micronutrients are removed from the above list, the high TF value obtained for Se (TF > 10 both in leaves and stems) is noteworthy. It has 
been shown that, at low concentrations, it is capable of acting as a growth stimulant and increasing plant efficiency, as well as conferring tolerance to abiotic stress in plants and protecting against oxidative damage [94].

From the results obtained, it can be seen that some elements can also accumulate in stems rather than in leaves; among these, there are some elements, such as $\mathrm{Cd}$ and $\mathrm{Pb}$, that may be toxic if they accumulate in leaves.

The remaining elements with an average TF $<1$ can be used in phytostabilisation processes, i.e., they accumulate in the soil matrix or in the plant root tissue, as in the case of $\mathrm{Cd}, \mathrm{Pb}$ and $\mathrm{Zn}$. Although the values obtained for $\mathrm{C}$ were close to 1 , this may be due to the greater structural complexity of the root or to the fact that the root functions as a nutrient sink [95].

The combination of BCF and TF values obtained indicate that this species shows an accumulating or indicator strategy, rather than an exclusor strategy [66] in the case of $\mathrm{Al}$, $\mathrm{B}, \mathrm{Co}, \mathrm{Cr}, \mathrm{Fe}, \mathrm{Rb}, \mathrm{Sr}, \mathrm{Ti}$ and $\mathrm{Tl}$, and, therefore, they can be eliminated by phytoextraction processes. As an example, the BCF value of $B$ was higher than 10 both for total and phytoavailable soil elements, whereas $\mathrm{Rb}$ and $\mathrm{Tl}$ show values higher than 10 for phytoavailable but between 1 and 10 for the total. The corresponding TFs indicate that the three elements remain accumulated, preferably in the aerial part of the plant.

This fact could predict the existence of other species in the plant community with bioindicator or even phytoremediation potential for other elements, because the elemental compositions should differ more among coexisting species to avoid competitive pressure [53].

\subsection{Influence of Total and Phytoavailable Soil Elements on P. spathulatus Communities}

Regarding the various indices obtained for the communities, most of the elements that showed significant correlations with them corresponded to their version as phytoavailable. Only Ca contents showed a correlation with some of the indices calculated for the $P$. spathulatus communities. $\mathrm{N}$ was shown to be a key element in the interpretation of dolomitophyly [14]; therefore, its higher abundance in the soil favours one, or a few, species, being predominant (Figure 7), that is, the abundance of $\mathrm{N}$ contributes to the fact that in this type of community (nano-chamaephytic scrub) some species become predominant while reducing the total number of species.
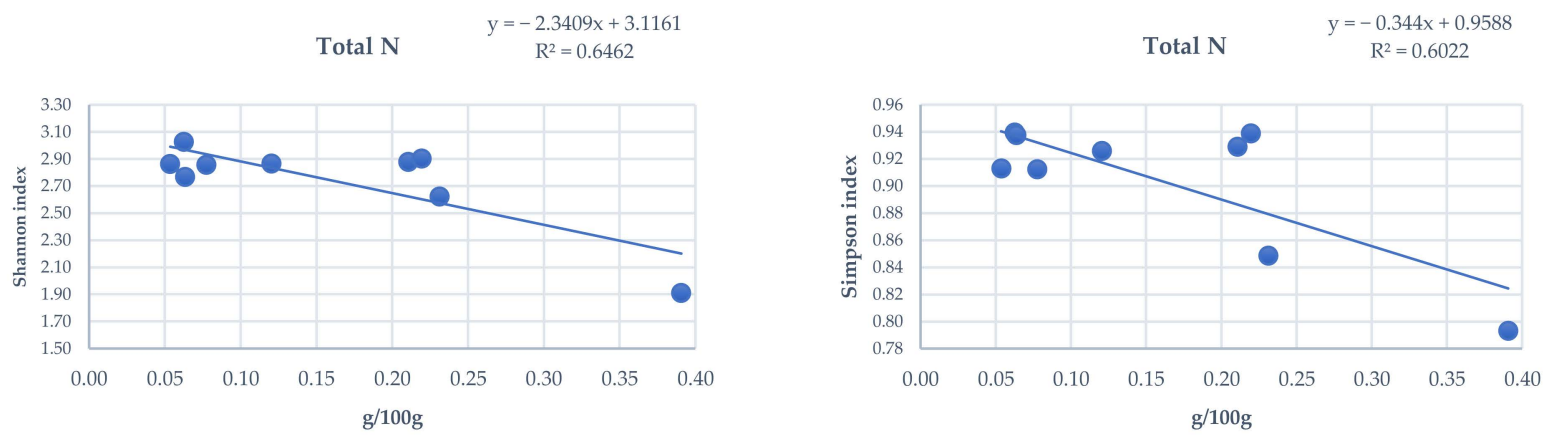

Figure 7. Relationship between the total $\mathrm{N}$ content of the soil and the Shannon diversity (left) and Simpson uniformity (right) indexes.

The variation observed in the Shannon index, which decreases with increasing total N in the soil, points in the same direction. The same influence seems to be exerted by K and $\mathrm{P}$, the other two elements in the trilogy of commercial fertilisers (i.e., the NPK), al-though this time in their phytoavailable form. Poverty in these fundamental macronutrients, therefore, seems to be a determining factor in understanding the nutritional stress to which plants in dolomitic outcrops are subjected and the constraints that this habitat imposes on their growth and, consequently, on their spatial occupation of the soil. In any case, the scarcity 
of $\mathrm{P}$ in the soil, below the values considered normal, and the ratio N:P (24.8) indicate this last element as the main limiting factor for plants in dolomite soils [4].

Total Ca contents appeared to be linked to the Menhinick richness index (Figure 8). In its phytoavailable version, Ca showed a very similar relationship to that described for total soil N. Considering both relationships, Ca abundance may play an important role in maintaining the diversity of this type of shrubland, preventing the dominance of a few species and, therefore, favouring its floristic richness.

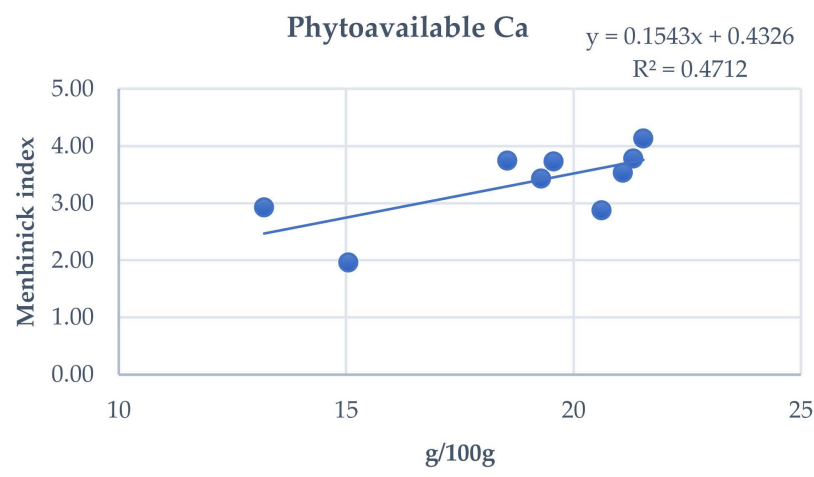

Figure 8. Relationship between the available Ca and the Menhinick richness index.

$\mathrm{Mg}$, another key element in the explanation of plant preference for dolomites, was correlated with vegetation cover, as its increase in phytoavailability seems to favour rarer and more dispersed communities (Figure 9) or, that is, it seems to limit their productivity.

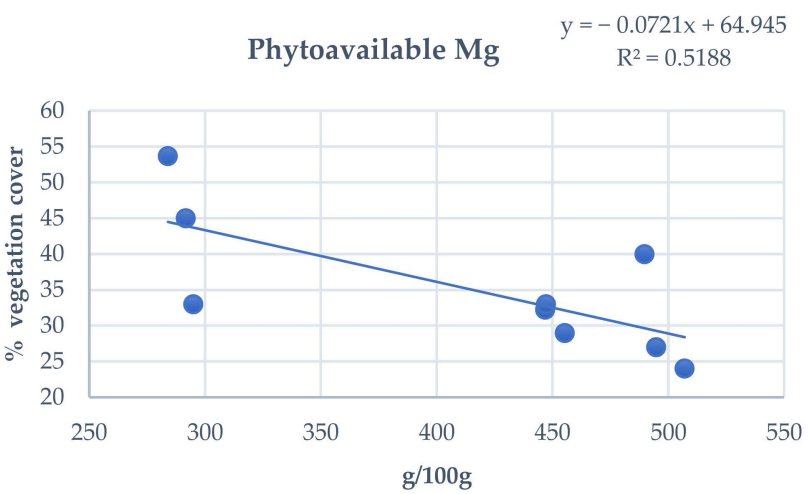

Figure 9. Relationship between available $\mathrm{Mg}$ and P. spathulatus scrub cover.

Other elements (e.g., As, Co, $\mathrm{Ti}$ and $\mathrm{Tl}$ ) also showed correlations with some of the ecological indices calculated. However, the low concentration of these elements and the scarce references to their role in plants, almost always related to their toxicity, make it advisable not to speculate about them. The pattern is, however, that their influence is in almost all cases as phytoavailable. Finally, B and Ni deserve a separate comment, also in the plant-available form. Ni seems to act by limiting the occurrence of some species, which is reflected in the Shannon index values (Figure 10). However, a firmer conclusion on this point would require an investigation of the influence of these elements on the two components of the Shannon index; that is, richness (number of species) and abundance [72]. Although this aspect was not the objective of this research, the relationship between $\mathrm{Ni}$ and the calculated richness indices indicates that species' richness is a key aspect.

From the results obtained, it is clear that dolomitic soils with a poor evolution (edaphogenesis) are very oligotrophic (scarcity of N, P and K) and that this characteristic, together with the abundance of $\mathrm{Ca}$ and $\mathrm{Mg}$, not only influences species such as P. spathulatus, but that its influence is even more general, also impacting the plant community of which it is a 
part. The role of $\mathrm{Ni}, \mathrm{B}$ and other elements that have also been pointed out in other sections of this work need to be further investigated.

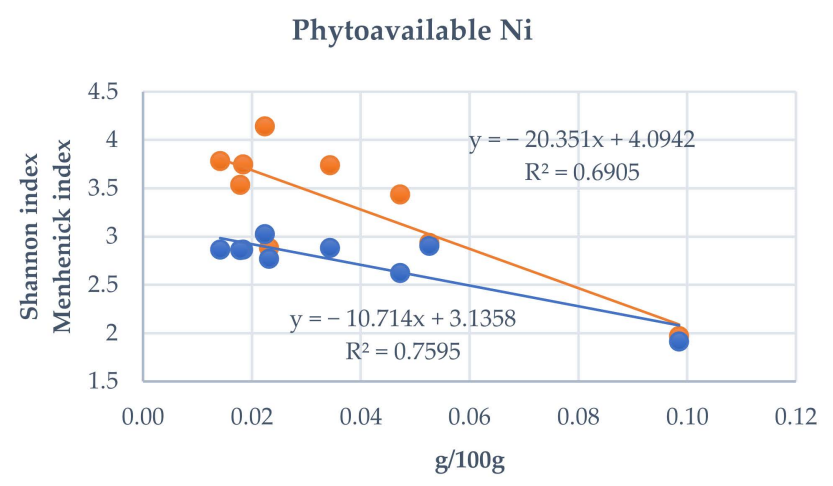

Figure 10. Relationship between the available Ni and Shannon diversity (orange) and Menhinick richness (blue) indexes.

\section{Conclusions}

The analyses of total mineral contents from the soil samples showed, in general, that all the localities had high concentrations of $\mathrm{C}, \mathrm{Ca}$ and $\mathrm{Mg}$. In addition, with regard to the essential microelements, the contents of $\mathrm{Fe}$ and $\mathrm{Mn}$ were remarkable, especially in the localities of Gador and Calar del Gallinero. To a lesser extent, the contents of B, Cu, Ni and $\mathrm{Zn}$ were also noteworthy. Furthermore, other elements such as $\mathrm{Pb}, \mathrm{Si}$ and $\mathrm{Tl}$ were also worth highlighting.

Regarding the phytoavailable mineral contents obtained from the soil samples, as in the previous case, the contents of $\mathrm{Ca}$ and $\mathrm{Mg}$ were remarkable, followed by $\mathrm{K}$ and $\mathrm{S}$. As in the case of serpentine and gypsum soils, the abundance and proportion of $\mathrm{Ca}$ and $\mathrm{Mg}$ stand out as key factors to understand the preference of some plants for dolomite soils. Regarding the microelements, Fe and Mn also stood out, in addition to the data obtained for $\mathrm{Al}$ and $\mathrm{Si}$. Therefore, the proportions of total soil elements and phytoavailable elements show a similar abundance pattern in most cases.

The data obtained from the foliar samples collected in the different sites indicate that this species has a fairly stable leaf ionomic composition, regardless of the location sampled. The elements that accumulate to a greater extent in the foliar samples are $\mathrm{Al}, \mathrm{B}, \mathrm{Fe}, \mathrm{Mn}, \mathrm{Tl}$ and $\mathrm{Zn}$, which were also found in high concentrations in the analysed soils.

With the exception of the BCFs obtained for some of the essential macronutrients, the reminder of the data were not much higher than 1 when total soil elements were used. However, the BCFs for the following elements were noteworthy: $\mathrm{Al}, \mathrm{B}, \mathrm{Cr}, \mathrm{Cu}, \mathrm{Fe}, \mathrm{Ni}, \mathrm{Rb}$, $\mathrm{S}, \mathrm{Ti}, \mathrm{Tl}$ and $\mathrm{Zn}$. In the case of BCFs obtained using the phytoavailable contents, elements such as $B$ and $T l$ showed values well above 10 .

In general, the resulting values for the TFs were higher than 1, indicating that the species studied has a great capacity to transport mineral elements through its conducting vessels.

The combination of both $\mathrm{BCF}>1$ and $\mathrm{TF}>1$ for some elements indicates that the plant species P. spathulatus can be used as a bioindicator of metaloids from the soil $(\mathrm{B}, \mathrm{Rb}$ or $\mathrm{Tl})$. This fact may predict the existence of other species in the plant community with bioindicator or even phytoremediation potential for several elements. From this point of view, the dolomitic flora has been little explored, unlike in serpentine or gypsum.

The high concentrations of $\mathrm{Ca}$ and $\mathrm{Mg}$, together with the scarcity of $\mathrm{N}, \mathrm{P}$ and $\mathrm{K}$, have a great influence on the species under study, and on the plant community to which it belongs. In the cases of $\mathrm{Ca}$ and $\mathrm{Mg}$, and despite their abundance in the soil, the contents in the plant are not remarkably high and present proportions similar to those found in other dolomite plants. Although $\mathrm{P}$ and $\mathrm{N}$ were shown as key elements, both for P. spathulatus and for the plant communities it inhabits, the proportion of these two elements, both in the soil and in 
the plant, point to the former as the main limiting factor. In addition, the possible impact of other elements such as B and Ni was observed, but further study should be carried out.

To the best of our knowledge, this is the first investigation that extensively describes the ionome of a dolomite plant species, P. spathulatus. The total and phytoavailable contents of the soil are related both to those of the plant, and to the diversity of the typical vegetal communities of this habitat. This is a first step to decipher and better understand the plant adaptations to a habitat that has large amounts of $\mathrm{Ca}$ and $\mathrm{Mg}$, is very poor in $\mathrm{N}$ and $\mathrm{P}$, and has striking proportions of some micronutrients.

Supplementary Materials: The following are available online at https:/ /www.mdpi.com/article/10 $.3390 /$ land10111253/s1, Table S1: Vouchers of the species P. spathulatus deposited in the herbarium of the University of Almería (HUAL), Table S2: Vegetation relevés (field inventory data per locality) included in the analyses. The coverage of each plant species is expressed as a percentage.

Author Contributions: Conceptualization, J.M.; Data curation, J.M. and E.M.; Formal analysis, J.M. and E.M.; Funding acquisition, J.M. and E.M.; Investigation, J.M., E.M., A.J.M.-F., E.S.-S. and F.M.-H.; Methodology, J.M. and E.M.; Project administration, J.M.; Resources, J.M.; Software, J.M., E.M., A.O.-Ú. and E.S.-S.; Supervision, J.M. and E.M.; Validation, J.M. and E.M.; Visualization, J.M. and E.M.; Writing—original draft, A.O.-Ú., J.M. and E.M.; Writing—review and editing, J.M., E.M. and A.J.M.-F. All authors have read and agreed to the published version of the manuscript.

Funding: This research was funded by the projects PPUENTE2020/008 ‘Diferenciación epigenética en Alyssum serpyllifolium y Hormathophylla en tres ambientes edáficos con ratios $\mathrm{Ca} / \mathrm{Mg}$ discordantes en el S de la Península Ibérica'; UAL2020-RNM-B2007 'Metabarcoding comparado de la rizosfera en tres ambientes edáficos singulares explotados por la minería: bases para el Desarrollo Sostenible funded by the University of Almería through the UAL-FEDER 2020 program.; CEIJ-009 'Integrated study of coastal sands vegetation (AREVEG II)' granted by CEI.MAR.

Institutional Review Board Statement: Not applicable.

Informed Consent Statement: Not applicable.

Data Availability Statement: The data presented in this study are available on Supplementary Material section.

Acknowledgments: This study was possible by the Projects 'Edaphic and nutritional characterization of dolomite vegetation and flora in the Betic mountain ranges and their relationship with other magnesium-rich environments (EU priority habitats)' CGL2007-63563/BOS, funded by the Spanish Ministry of Science and Innovation, and through the projects 'Assessment, Monitoring and Applied Scientific Research for Ecological Restoration of Gypsum Mining Concessions (Majadas Viejas and Marylen) and Spreading of Results (ECORESGYP)' sponsored by the company Explotaciones Río De Aguas S.L. (Torralba Group) and 'Provision of services, monitoring and evaluation of the environmental restoration of the mining concessions Los Yesares, María Morales and El Cigarrón' sponsored by the company Saint Gobain Placo Ibérica S.A. The sponsors had no role in the design, execution, interpretation, or writing of the study. We thank Beatrice Antolin for reviewing the English translation of the text.

Conflicts of Interest: The authors declare that they have no known competing financial interests or personal relationships that could have appeared to influence the work reported in this paper.

\section{References}

1. Unger, F. Ueber den Einfluss des Bodens auf die Vertheilung der Gewächse: Nachgewiesen in der Vegetation des nordöstlichen Tirol's; Bei Rohrmann und Schweigerd: Vienna, Austria, 1836. [CrossRef]

2. Thurmann, J. Essai de Phytostatique Appliqué à la Chaîne du Jura et aux Contrées Voisines: Ou Étude de la Dispersion des Plantes Vasculaires Envisagée Principalement Quant à L'influence des Roches Soujacentes (Volume 1); Jent et Gassmann: Bern, Switzerland, 1849. [CrossRef]

3. Kruckeberg, A.R. Geology and Plant Life: The Effects of Landforms and Rock Types on Plants; University of Washington Press: Washington, DC, USA, 2002.

4. Mota, J.; Garrido-Becerra, J.; Merlo, M.; Medina-Cazorla, J.; Sánchez-Gómez, P. The edaphism: Gypsum, dolomite and serpentine flora and vegetation. In The Vegetation of the Iberian Peninsula; Loidi, J., Ed.; Springer Nature: Basel, Switzerland, 2017. [CrossRef]

5. Schimper, A.F.W.; Fisher, W.R. Plant-Geography upon a Physiological Basis; Clarendon Press: Oxford, UK, 1902. [CrossRef] 
6. Rivas-Goday, S. Flora Serpentinícola Española: Nota Primera (Edafismos Endémicos del Reino de Granada); Real Academia de Farmacia: Madrid, Spain, 1969.

7. Merlo, M.; Mota, J.; Cabello, J.; Alemán, M. La gipsofilia en plantas: Un apasionante edafismo. Investig. Gestión 1998, 3, 103-112.

8. Mota, J.; Merlo, E.; Pérez-García, F.; Garrido-Becerra, J.; Martínez-Hernández, F.; Sánchez-Gómez, P.; Gil de Carrasco, C. Plants growing on unusual substrates: The edaphism. Notes from the antipodes (Iberian Peninsula). In Proceedings and Abstracts New Zealand: New home, New Habitat; Publishers Association of New Zealand Inc.: Palmerston North, New Zealand, 2007.

9. Proctor, J. Vegetation and soil and plant chemistry on ultramafic rocks in the tropical Far East. Perspect. Plant Ecol. Evol. Syst. 2003, 6, 105-124. [CrossRef]

10. Rajakaruna, N. The edaphic factor in the origin of plant species. Int. Geol. Rev. 2004, 46, 471-478. [CrossRef]

11. Mota, J.; Medina-Cazorla, J.; Navarro, F.; Pérez-García, F.; Pérez-Latorre, A.; Sánchez-Gómez, P.; Merlo, M. Dolomite flora of the baetic ranges glades (South Spain). Flora Morphol. Distrib. Funct. Ecol. Plants 2008, 203, 359-375. [CrossRef]

12. Merlo, M.; Mota, J.; Sánchez-Gómez, P. Ecofisiología y adaptaciones de las plantas vasculares a las características físicas y químicas de sustratos especiales. In Diversidad Vegetal de las Yeseras Ibéricas; Guirado Romero, J.S., Mota, J., Sánchez Gómez, P., Eds.; ADIF-Mediterráneo Asesores Consultores: Almería, Spain, 2011.

13. Merlo, M.E.; Garrido-Becerra, J.A.; Mota, J.F.; Salmerón-Sánchez, E.; Martínez-Hernández, F.; Mendoza-Fernández, A.; PérezGarcía, F.J. Threshold ionic contents for defining the nutritional strategies of gypsophile flora. Ecol. Indic. 2019, 97, $247-259$. [CrossRef]

14. Mota, J.; Merlo, E.; Martínez-Hernández, F.; Mendoza-Fernández, A.; Pérez-García, F.; Salmerón-Sánchez, E. Plants on RichMagnesium Dolomite Barrens: A Global Phenomenon. Biology 2021, 10, 38. [CrossRef] [PubMed]

15. Mendoza-Fernández, A.J.; Mota, J.F. Red Lists versus nature protection Acts: New analytical and numerical method to test threat trends. Biodiv. Conserv. 2016, 25, 239-260. [CrossRef]

16. Nunes, L.J.R.; Raposo, M.A.M.; Gomes, C.J.P. The Impact of Tourism Activity on Coastal Biodiversity: A Case Study at Praia da Cova Redonda (Algarve-Portugal). Environments 2020, 7, 88. [CrossRef]

17. Salmerón-Sánchez, E. Diversidad Genética, Estructura Poblacional, Filogeografía y Filogenia de Especies Dolomitícolas Presentes en las Cordilleras Béticas; Universidad Almería: Almería, Spain, 2018.

18. Chilingar, G.; Bissell, H.; Wolf, K. Diagenesis of carbonate rocks. Dev. Sedimentol. 1967, 8, 179-322. [CrossRef]

19. Pérez-García, F.J.; Medina-Cazorla, J.M.; Martínez-Hernández, F.; Garrido-Becerra, J.A.; Mendoza-Fernández, A.J.; SalmerónSánchez, E.; Mota, J.F. Iberian Baetic endemic flora and the implications for a conservation policy. Ann. Bot. Fenn. 2012, 49 , 43-54. [CrossRef]

20. Pérez-García, F.J.; Merlo, M.E.; Martínez-Hernández, F.; Medina-Cazorla, J.M.; Mendoza-Fernández, A.J.; Garrido-Becerra, J.A.; Salmerón-Sánchez, E.; Mota, J.F. Syntaxa-area relationships, lessons from the vegetation of the Betic high mountain ranges (southern Spain). Phytocoenologia 2014, 44, 309-323. [CrossRef]

21. Parolly, G.; Hein, P. Arabis lycia (Cruciferae), a new chasmophyte from the Taurus Mts, Turkey, and notes on related species. Willdenowia 2014, 30, 293-304. [CrossRef]

22. Ritter-Studnička, H. Flora and vegetation on dolomites of Bosnia and Herzegovina (I-Konjic). God. Biol. Inst. Sarajevu 1956, 9 , 73-122.

23. Brullo, C.; Brullo, S.; Giusso, G. Considerations on the endemic flora of Sicily. Islands and Plants: Preservation and Understanding of Flora on Mediterranean Islands. In Proceedings of the 2nd Botanical Conference in Menorca, Proceedings and Abstracts, Menorca, Spain, 26-30 April 2013.

24. Vogiatzakis, I.; Griffiths, G. A GIS-based empirical model for vegetation prediction in Lefka Ori, Crete. Plant Ecol. 2006, 184, 311-323. [CrossRef]

25. Dickoré, W.; Nüsser, M. Flora of Nanga Parbat (NW Himalaya, Pakistan): An annotated inventory of vascular plants with remarks on vegetation dynamics. Englera 2000, 19, 3-253. [CrossRef]

26. Reid, J.; Hill, R.; Brown, M.; Hovenden, M. Vegetation of Tasmania. Nord. J. Bot. 1999, 19, 622. [CrossRef]

27. Larson, D.; Matthes, U.; Kelly, P. Cliff ecology: Pattern and process in cliff ecosystems; Cambridge University Press: Cambridge, UK, 2005.

28. Mota, J.; Peñas, J.; Cabello, J. Scree and ruderal weed vegetation of Andalusian highlands (South Spain). Fitosociologia 1997, 32, 229-237.

29. Rivas Goday, S.; Mayor López, M. Aspectos de la vegetación y flora orófila del Reino de Granada. An. Real Acad. Farm. 1966, 31, 345-400.

30. Mota, J.F.; Valle, F.; Cabello, J. Dolomitic vegetation of South Spain. Vegetatio 1993, 109, 29-45. [CrossRef]

31. Pérez-Latorre, A. Restauración vegetal de extracciones de áridos dolomíticos en la Costa del Sol occidental (Sierra de Mijas, Málaga). Ecología 1998, 12, 123-134.

32. Medina-Cazorla, J.; Pérez-García, F.; Garrido-Becerra, J.; Martínez-Hernández, F.; Mendoza, A.; Romera, M.; Mota, J. Análisis biogeográfico de la flora de dolomías de Andalucía: Ensayo preliminar. In Ambientes Mediterráneos. Funcionamiento, Biodiversidad y Conservación de los Ecosistemas Mediterráneos; Colección Medio Ambiente: Almería, Spain, 2007.

33. Medina-Cazorla, J.M.; de Carrasco, C.G.; Merlo, M.E.; Martínez-Hernández, F.; Garrido-Becerra, J.A.; Salmerón, E.; Mendoza, A.J.; Pérez-García, F.J.; Mota, J.F. The dolomite shrublands of the Convolvuletalia boissieri order and their preservation by means of the Habitats Directive. Acta Bot. Gall. 2010, 157, 611-625. [CrossRef] 
34. Medina-Cazorla, J.M.; Garrido-Becerra, J.A.; Fernández, A.M.; Pérez-García, F.J.; Salmerón, E.; Gil, C.; Poveda, J.F.M. Biogeography of the Baetic Ranges (SE Spain): A historical approach using cluster and parsimony analyses of endemic dolomitophytes. Plant Biosyst. 2010, 144, 111-120. [CrossRef]

35. Navarro-Fernández, C.M.; Aroca, R.; Barea, J.M. Influence of arbuscular mycorrhizal fungi and water regime on the development of endemic Thymus species in dolomitic soils. Appl. Soil Ecol. 2011, 48, 31-37. [CrossRef]

36. Alonso, C.; García-Sevilla, M. Strong inbreeding depression and individually variable mating system in the narrow endemic Erodium cazorlanum (Geraniaceae). An. Jard. Bot. Madr. 2013, 70, 72-80. [CrossRef]

37. Salmerón-Sánchez, E.; Fuertes-Aguilar, J.; Španiel, S.; Pérez-García, F.J.; Merlo, E.; Garrido-Becerra, J.A.; Mota, J. Plant evolution in alkaline magnesium-rich soils: A phylogenetic study of the mediterranean genus Hormathophylla (Cruciferae: Alysseae) based on nuclear and plastid sequences. PLoS ONE 2018, 13, e0208307. [CrossRef]

38. Salmerón-Sánchez, E.; Merlo, M.E.; Medina-Cazorla, J.M.; Pérez-García, F.J.; Martínez-Hernández, F.; Garrido-Becerra, J.A.; Mendoza-Fernández, A.J.; Valle, F.; Mota, J.F. Variability, genetic structure and phylogeography of the dolomitophilous species Convolvulus boissieri (Convolvulaceae) in the Baetic ranges, inferred from AFLPs, plastid DNA and ITS sequences. Bot. J. Linn. 2014, 176, 506-523. [CrossRef]

39. Mota, J.; Salmerón-Sánchez, E.; Pérez-García, F.; Martínez-Hernández, F.; Mendoza-Fernández, A.; Medina-Cazorla, J.; Merlo, M. Catálogo Delphi de la flora edafoendémica de los blanquizales dolomíticos béticos: Bases para su conocimiento y conservación. In Biología de la Conservación de Plantas en Sierra Nevada: Principios y Retos Para su Preservación; Peñas de Giles, J., Lorite, J., Eds.; Editorial Universidad de Granada: Granada, Spain, 2019.

40. Médail, F.; Quézel, P. Biodiversity hotspots in the Mediterranean basin: Setting global conservation priorities. Conserv. Biol. 1999, 13, 1510-1513. [CrossRef]

41. Mendoza-Fernández, A.J.; Pérez-García, F.J.; Martínez-Hernández, F.; Salmerón-Sánchez, E.; Lahora, A.; Merlo, M.E.; Mota, J.F. Red List Index application for vascular flora along an altitudinal gradient. Biodivers. Conserv. 2019, 28, 1029-1048. [CrossRef]

42. Salmerón-Sánchez, E.; Mendoza-Fernández, A.J.; Lorite, J.; Mota, J.F.; Peñas, J. Plant conservation in Mediterranean-type ecosystems. Mediterr. Bot. 2021, 42, e71333. [CrossRef]

43. Anonymous. Council Directive 92/43/EEC of 21 May 1992 on the conservation of natural habitats and of wild fauna and flora. DOCE 1992, 206, 7-50.

44. Bobo-Pinilla, J.; Salmerón-Sánchez, E.; Mota, J.F.; Peñas, J. Genetic conservation strategies of endemic plants from edaphic habitat islands: The case of Jacobaea auricula (Asteraceae). J. Nat. Conserv. 2021, 61, 126004. [CrossRef]

45. Watanabe, T.; Maejima, E.; Yoshimura, T.; Urayama, M.; Yamauchi, A.; Owadano, M.; Shinano, T. The ionomic study of vegetable crops. PLoS ONE 2016, 11, e0160273. [CrossRef]

46. Baxter, I.R.; Vitek, O.; Lahner, B.; Muthukumar, B.; Borghi, M.; Morrissey, J.; Salt, D.E. The leaf ionome as a multivariable system to detect a plant's physiological status. Proc. Natl. Acad. Sci. USA 2008, 105, 12081-12086. [CrossRef] [PubMed]

47. Chao, D.; Gable, K.; Chen, M.; Baxter, I.; Dietrich, C.; Cahoon, E.; Salt, D. Sphingolipids in the root play an important role in regulating the leaf ionome in Arabidopsis thaliana. Plant Cell 2011, 23, 1061-1081. [CrossRef] [PubMed]

48. Watanabe, T.; Broadley, M.; Jansen, S.; White, P.; Takada, J.; Satake, K.; Osaki, M. Evolutionary control of leaf element composition in plants. New Phytol. 2007, 174, 516-523. [CrossRef] [PubMed]

49. Sha, Z.; Oka, N.; Watanabe, T.; Tampubolon, B.; Okazaki, K.; Osaki, M.; Shinano, T. Ionome of soybean seed affected by previous cropping with mycorrhizal plant and manure application. J. Agric. Food Chem. 2012, 60, 9543-9552. [CrossRef]

50. White, P.; Broadley, M.; Thompson, J.; McNicol, J.; Crawley, M.; Poulton, P.; Johnston, A. Testing the distinctness of shoot ionomes of angiosperm families using the Rothamsted Park Grass Continuous Hay Experiment. New Phytol. 2012, 196, 101-109. [CrossRef]

51. Salt, D.E.; Baxter, I.; Lahner, B. Ionomics and the study of the plant ionome. Annu. Rev. Plant Biol. 2008, 59, 709-733. [CrossRef]

52. Kattge, J.; Diaz, S.; Lavorel, S.; Prentice, I.C.; Leadley, P.; Bönisch, G.; Wirth, C. TRY-a global database of plant traits. Glob. Chang. Biol. 2011, 17, 2905-2935. [CrossRef]

53. Peñuelas, J.; Fernández-Martínez, M.; Ciais, P.; Jou, D.; Piao, S.; Obersteiner, M.; Sardans, J. The bioelements, the elementome, and the biogeochemical niche. Ecology 2019, 100, e02652. [CrossRef]

54. Müllerová, V.; Hejcman, M.; Hejcmanová, P.; Pavlů, V. Effect of fertilizer application on Urtica dioica and its element concentrations in a cut grassland. Acta Oecol. 2014, 59,1-6. [CrossRef]

55. Wang, M.; Moore, T. Carbon, nitrogen, phosphorus, and potassium stoichiometry in an ombrotrophic peatland reflects plant functional type. Ecosystems 2014, 17, 673-684. [CrossRef]

56. Carreira, J.; Niell, F.; Lajtha, K. Soil nitrogen availability and nitrification in Mediterranean shrublands of varying fire history and successional stage. Biogeochemistry 1994, 26, 189-209. [CrossRef]

57. Brady, K.; Kruckeberg, A.; Bradshaw, H., Jr. Evolutionary ecology of plant adaptation to serpentine soils. Annu. Rev. Ecol. Evol. Syst. 2005, 36, 243-266. [CrossRef]

58. Oze, C.; Skinner, C.; Schroth, A.; Coleman, R. Growing up green on serpentine soils: Biogeochemistry of serpentine vegetation in the Central Coast Range of California. Appl. Geochem. 2008, 23, 3391-3403. [CrossRef]

59. Visscher, A.; Paul, A.; Kirst, M.; Guy, C.; Schuerger, A.; Ferl, R. Growth performance and root transcriptome remodeling of Arabidopsis in response to Mars-like levels of magnesium sulfate. PLoS ONE 2010, 5, e12348. [CrossRef] 
60. Guo, W. Magnesium homeostasis mechanisms and magnesium use efficiency in plants. In Plant Macronutrient Use Efficiency: Molecular and Genomic Perspectives in Crop Plants; Hossain, M.A., Kamiya, T., Burritt, D., Tran, L.S.P., Fujiwara, T., Eds.; Academic Press: Cambridge, MA, USA, 2017; pp. 197-213. [CrossRef]

61. Cunningham, S.; Berti, W.; Huang, J. Phytoremediation of contaminated soils. Trends Biotechnol. 1995, 13, 393-397. [CrossRef]

62. Thangavel, P.; Subbhuraam, C. Phytoextraction: Role of hyperaccumulators in metal contaminated soils. Proc. Indian Natl. Sci. Acad. 2004, 70, 109-130.

63. Delgadillo-López, A.; González-Ramírez, C.; Prieto-García, F.; Villagómez-Ibarra, J.; Acevedo-Sandoval, O. Fitorremediación: Una alternativa para eliminar la contaminación. Trop. Subtrop. Agroecosyst. 2011, 14, 597-612.

64. Brooks, R. Plants That Hyperaccumulate Heavy Metals, Their Role in Phytoremediation, Microbiology, Archaeology, Mineral Exploration and Phytomining; Cab International: New York, NY, USA, 1998.

65. Buscaroli, A. An overview of indexes to evaluate terrestrial plants for phytoremediation purposes. Ecol. Indic. 2017, 82, 367-380. [CrossRef]

66. Baker, A. Accumulators and excluders-strategies in the response of plants to heavy metals. J. Plant Nutr. 1981, 3, 643-654. [CrossRef]

67. Mota-Merlo, M.; Martos, V. Use of machine learning to establish limits in the classification of hyperaccumulator plants growing on serpentine, gypsum and dolomite soils. Mediterr. Bot. 2021, 42, e67609. [CrossRef]

68. Castroviejo, S. Flora Iberica. Plantas Vasculares de la Península Ibérica e Islas Baleares; Real Jardín Botánico de Madrid: Madrid, Spain, 2012.

69. Heinert, M.; Endara, A.; Solórzano, H. Plasma acoplado inductivamente en espectroscopia de emisión óptica (ICP-OES). Recimundo 2020, 4, 4-12. [CrossRef]

70. Abedin, J.; Beckett, P.; Spiers, G. An evaluation of extractants for assessment of metal phytoavailability to guide reclamation practices in acidic soilscapes in northern regions. Can. J. Soil Sci. 2012, 92, 253-268. [CrossRef]

71. Quevauviller, P.; Lachica, M.; Barahona, E.; Gomez, A.; Rauret, G.; Ure, A.; Muntau, H. Certified reference material for the quality control of EDTA-and DTPA-extractable trace metal contents in calcareous soil (CRM 600). Fresenius J. Anal. Chem. 1998, 360, 505-511. [CrossRef]

72. Hammer, Ø.; Harper, D.A.; Ryan, P. PAST: Paleontological statistics software package for education and data analysis. Paleontol. Electron. 2001, 4, 9.

73. IBM Corporation. Released. SPSS Software Version 26.0; IBM: Armonk, NY, USA, 2019.

74. Jiménez Terrón, I. El patrimonio minero. In Sierra de Gádor: Patrimonio Natural e Infraestructura Verde de Almería; CAESCG: Almería, Spain, 2016.

75. Marschner, H. Marschner's Mineral Nutrition of Higher Plants; Academic Press: Adelaide, Australia, 2011.

76. Goldberg, S. Interaction of aluminium and iron oxides and clay minerals and their effect on soil physical properties: A review. Commun. Soil Sci. Plant Anal. 1989, 20, 1181-1207. [CrossRef]

77. Baker, A.; Reeves, R.; Hajar, A. Heavy metal accumulation and tolerance in British populations of the metallophyte Thlaspi caerulescens J. \& C. Presl (Brassicaceae). New Phytol. 1994, 127, 61-68. [CrossRef]

78. Poschenrieder, C.; Llugany, M.; Lombini, A.; Dinelli, E.; Bech, J.; Barceló, J. Smilax aspera L. an evergreen Mediterranean climber for phytoremediation. J. Geochem. Explor. 2012, 123, 41-44. [CrossRef]

79. Camacho-Cristóbal, J.; Rexach, J.; González-Fontes, A. Boron in plants: Deficiency and toxicity. J. Integr. Plant Biol. 2008, 50, 1247-1255. [CrossRef]

80. Abreu, C.; Raij, B.; Abreu, M.; Gonzalez, A.P. Routine soil testing to monitor heavy metals and boron in soils. Sci. Agric. 2005, 62, 1-6. [CrossRef]

81. Babaoğlu, M.; Gezgın, S.; Topal, A.; Sade, B.; Dural, H. Gypsophila sphaerocephala Fenzl ex Tchihat.: A boron hyperaccumulator plant species that may phytoremediate soils with toxic B levels. Turk. J. Bot. 2004, 28, 273-278.

82. Jiang, Y.; Xia, W.; Zhang, B.; Pan, X.; Liu, W.; Jin, S.; Li, Y. Predictors of thallium exposure and its relation with preterm birth. Environ. Pollut. 2018, 233, 971-976. [CrossRef]

83. Vaněk, A.; Grösslová, Z.; Mihaljevič, M.; Ettler, V.; Trubač, J.; Chrastný, V.; Ash, C. Thallium isotopes in metallurgical wastes/contaminated soils: A novel tool to trace metal source and behavior. J. Hazard. Mater. 2018, 343, 78-85. [CrossRef] [PubMed]

84. Biagioni, C.; D’Orazio, M.; Lepore, G.O.; d'Acapito, F.; Vezzoni, S. Thallium-rich rust scales in drinkable water distribution systems: A case study from northern Tuscany, Italy. Sci. Total Environ. 2017, 587, 491-501. [CrossRef]

85. Pavoni, E.; Covelli, S.; Adami, G.; Baracchini, E.; Cattelan, R.; Crosera, M.; Petranich, E. Mobility and fate of Thallium and other potentially harmful elements in drainage waters from a decommissioned $\mathrm{Zn}-\mathrm{Pb}$ mine (North-Eastern Italian Alps). J. Geochem. Explor. 2018, 188, 1-10. [CrossRef]

86. Karbowska, B.; Rębiś, T.; Milczarek, G. Electrode modified by reduced graphene oxide for monitoring of total thallium in grain products. Int. J. Environ. Res. Public Health 2018, 15, 653. [CrossRef] [PubMed]

87. Shrivastava, R.; Upreti, R.; Seth, P.; Chaturvedi, U. Effects of chromium on the immune system. FEMS Immunol. Med. Microbiol. 2002, 34, 1-7. [CrossRef]

88. Shanker, A.; Cervantes, C.; Loza-Tavera, H.; Avudainayagam, S. Chromium toxicity in plants. Environ. Int. 2005, 31, 739-753. [CrossRef] 
89. Zayed, A.; Terry, N. Chromium in the environment: Factors affecting biological remediation. Plant Soil 2003, $249,139-156$. [CrossRef]

90. Boyd, R.; Martens, S. Nickel hyperaccumulated by Thlaspi montanum var. montanum is acutely toxic to an insect herbivore. Oikos 1994, 70, 21-25. [CrossRef]

91. Boyd, R.; Moar, W. The defensive function of Ni in plants: Response of the polyphagous herbivore Spodoptera exigua (Lepidoptera: Noctuidae) to hyperaccumulator and accumulator species of Streptanthus (Brassicaceae). Oecologia 1999, 118, 218-224. [CrossRef]

92. Boyd, R.; Shaw, J.; Martens, S. Nickel hyperaccumulation defends Streptanthus polygaloides (Brassicaceae) against pathogens. Am. J. Bot. 1994, 81, 294-300. [CrossRef]

93. Ghaderian, Y.; Lyon, A.; Baker, A. Seedling mortality of metal hyperaccumulator plants resulting from damping off by Pythium spp. New Phytol. 2000, 146, 219-224. [CrossRef] [PubMed]

94. Hasanuzzaman, M.; Bhuyan, M.; Raza, A.; Hawrylak-Nowak, B.; Matraszek-Gawron, R.; Al Mahmud, J.; Fujita, M. Selenium in plants: Boon or bane? Environ. Exp. Bot. 2020, 104170. [CrossRef]

95. Taiz, L.; Zeiger, E.; Moller, I.M.; Murphy, A. (Eds.) Plant Physiology and Development, 6th ed.; Sinauer Associates: Sunderland, CT, USA, 2015. 